Graduate Institute of International and Development Studies

International Economics Department

Working Paper Series

Working Paper No. HEIDWP10-2019

\title{
Tracking Foreign Capital: \\ The Effect of Capital Inflows on Bank Lending in the UK
}

\author{
Christiane Kneer \\ Bank of England \\ Alexander Raabe \\ Graduate Institute, Geneva
}

This paper has also been published as Bank of England Staff Working Paper No. 804.

June 2019

Chemin Eugène-Rigot 2

P.O. Box 136

CH - 1211 Geneva 21

Switzerland

(C) The Authors. All rights reserved. Working Papers describe research in progress by the author(s) and are published to elicit comments and to further debate. No part of this paper may be reproduced without the permission of the authors. 


\title{
Tracking Foreign Capital: The Effect of Capital Inflows on Bank Lending in the UK
}

\author{
Christiane Kneer* $\quad$ Alexander Raabe ${ }^{\dagger}$
}

\begin{abstract}
This paper examines how UK banks channel capital inflows to the individual sectors of the domestic economy and to overseas residents. Information on the source country of foreign capital deposited with UK banks allows us to construct a novel Bartik instrument for capital inflows. Our results suggest that foreign funds boost bank lending to the domestic economy. This result is due to the positive effect of capital inflows on bank lending to non-financial firms and to other domestic financial institutions. Banks do not channel capital inflows directly to households or the public sector. Much of the foreign capital is also channeled back abroad, reflecting the role of the UK as a global financial center.
\end{abstract}

Key words: capital flows, bank lending, credit allocation, international finance, instrumental variables, international financial linkages

JEL classification: F21, F30, F32, F34, G00, G21

\footnotetext{
${ }^{*}$ Corresponding author at: Bank of England, 20 Moorgate, London, EC2R 6DA, United Kingdom.

Email: christiane.kneer@bankofengland.co.uk

${ }^{\dagger}$ Graduate Institute Geneva. Email: alexander.raabe@graduateinstitute.ch
}

We are grateful to Stijn Claessens, Lerby Ergun, Ralph de Haas, Mathias Hoffmann, Ranko Jelic, Şebnem Kalemli-Özcan, Kalina Manova, Steven Ongena, Daniel Paravisini, Cédric Tille, Neeltje van Horen and Richard Varghese for helpful discussions. We are particularly grateful to Filipa Sá. We would also like to thank participants at the Bank of Canada Conference on Capital Flows in Advanced Economies, the DIW Finance and Development Workshop and the Belgrade Young Economists Conference, and seminar participants at the Bank of England and the Graduate Institute Geneva for useful comments and suggestions. This paper was previously circulated under the title "Follow the Money - The Effect of Capital Inflows on Bank Lending in the UK".

The views expressed in this paper are those of the authors and cannot be taken to represent those of the Bank of England or to state Bank of England policy. This paper should therefore not be reported as representing the views of the Bank of England or members of the Monetary Policy Committee, Financial Policy Committee or Prudential Regulation Committee. 


\section{Introduction}

Large and volatile capital flows have become an important feature of the global financial system since the 1990s. Capital inflows have funded productive investment in recipient countries but they have also driven credit booms and asset price bubbles, forcing costly adjustments when funding was withdrawn and flows reversed. ${ }^{1}$ In many advanced economies, the largest and most volatile component of these flows are "other investment flows" - the foreign capital which flows into banks and other financial institutions. But where do these funds ultimately go ? How financial institutions use the foreign capital and which sectors they channel the funds to has important implications for the real economy. The allocation of foreign funds by financial institutions may determine which sectors of the economy are prone to credit booms or face refinancing risks when funding dries up. Foreign funding can also shape the economic structure of recipient countries as financial intermediaries adjust the composition of their loan portfolios to match the currency and maturity profile of their funding base.

This paper traces out the path of foreign capital to the various sectors of the UK economy. We study bank balance sheets to assess how banks channel foreign capital to the individual sectors of the domestic economy and to foreign counterparties. Despite the importance of the allocation of foreign funding across sectors in shaping the nature of credit booms and busts and in influencing the structure of the domestic economy, evidence on the ultimate recipients of capital inflows is scarce. Several studies document the relationship between capital inflows and lending growth for specific sectors of the economy such as the corporate sector (Baskaya, Di Giovanni, Kalemli-Özcan, Peydró, and Ulu (2017a); Igan and Tan (2017)) or residential housing (Sá, Towbin, and Wieladek (2014)). Our paper provides a more comprehensive picture of the allocation of foreign funds by tracing capital inflows to all economic sectors.

To track foreign capital, we examine detailed, quarterly balance sheet data of UK-resident banks for the period from 1998Q1 to 2016Q4. ${ }^{2}$ Banks' balance sheets are an ideal source for studying the allocation of foreign funds given that banks are recipients of large capital inflows but also

\footnotetext{
${ }^{1}$ See for example evidence by Mendoza and Terrones (2012); Calderon and Kubota (2012); Lane and McQuade (2014); Elekdag and Wu (2013); Ghosh, Ostry, and Qureshi (2016) on the relationship between capital inflows and credit booms. For evidence on the relationship between capital inflows and asset prices, see for example Sá, Towbin, and Wieladek (2014); Taguchi, Sahoo, and Nataraj (2015); Tillmann (2013).

${ }^{2}$ We use the phrase "UK banks" or "banks in the UK" as a shorthand for UK-resident banks in the remainder of the paper.
} 
providers of credit to the rest of the economy. We examine the effect of capital inflows on bank lending to domestic households, firms, the public sector, banks and other financial institutions, and on lending to non-residents. Within the household sector we differentiate between mortgage and consumer credit. We also study the industry breakdown of lending to the corporate sector.

To establish causality between capital inflows and bank lending to individual sectors we introduce a novel instrument for capital inflows into banks. Foreign funding may not be randomly allocated across banks in the UK and could be endogenous to bank lending. Some banks might for example attract foreign funding in order to meet higher demand for credit by their customer base. Improved growth prospects of a sector could boost lending growth but also lead to larger capital inflows. To address these endogeneity issues, we construct a Bartik instrument for capital inflows similar to the instrument for labor inflows that is widely used in the migration literature to examine local effects of immigration in host countries (e.g. Card (2005); Cortes (2008); Sá (2016)).

To construct our instrument, we exploit detailed data about the country of origin of the foreign capital that is deposited with each of the UK banks in our sample. The instrument uses information about the historical distribution of funding from a foreign country across UK banks to allocate subsequent capital inflows from this country across recipient UK banks. The instrument for capital inflows into bank b over the quarter is therefore determined by two components: first, capital inflows from the depositor countries of bank b which flow into the entire UK banking sector during that quarter; and second, the historical share of funds from these countries which were deposited with bank b during some initial period. Neither of these components should affect bank lending, other than through their effect on capital inflows into individual banks. The historical distribution of foreign funding has predictive power for the subsequent allocation of foreign capital across UK banks. This is due to branching and subsidiary networks of UK-resident banks abroad which facilitate transactions with particular UK banks, and due to intragroup flows and persistent ties between foreign depositors and UK banks.

As a global financial center with a large and sophisticated domestic credit market, the UK provides a suitable testing ground to study the relationship between capital inflows and sectoral lending. The UK hosts a large and heterogeneous set of banks with headquarters in different countries around the world. Banks have large external liabilities and are therefore sensitive to movements in funding from abroad. Figure 1 shows that UK banks' external liabilities increased rapidly in the 
2000s, peaked at almost $230 \%$ of GDP at the beginning of 2008 and contracted sharply when foreign capital was withdrawn during the Global Financial Crisis. Within two quarters external liabilities fell by $35 \%$ of annualized GDP, squeezing banks' balance sheets. The banking sector deleveraged over much of the post-crisis period, a process which was only reversed in 2016. In mid-2018, gross external liabilities of financial institutions in the UK amounted to 144\% of GDP. Large withdrawals of foreign capital or failure to refinance these external liabilities could lead to a tightening of domestic credit conditions, and would likely hit those sectors which benefitted most from capital inflows. Such a shock could be cushioned by a repatriation of UK banks' assets abroad. However, during most of the period that we study, the banking sector in the UK was a net borrower from the rest of the world and external liabilities exceeded external assets.

Figure 2 shows the substantial gross inflows into financial institutions resident in the UK which contributed to the build-up of these stocks. Around the time of the Global Financial Crisis, inflows and outflows of foreign capital reached record highs of nearly 100\% of quarterly GDP. But flows were also large in non-crisis times such as the first half of the 2000s. These aggregate flows mask substantial heterogeneity across UK banks which are important in determining credit outcomes. Aggregate capital inflows can coincide with individual UK banks experiencing withdrawals of foreign funding and this can reduce credit availability for particular sectors of the domestic economy. This underscores the need to analyze capital flow data at the level of the individual bank rather than at the country-level.

Our results for the period 2001Q1-2016Q4 suggest that capital inflows boost bank lending to the domestic economy. We find that an increase in capital inflows equal to one percent of a bank's total liabilities is associated with an increase in domestic credit growth by 0.8 percentage points. This is driven by lending to the corporate sector and lending to other domestic financial institutions. ${ }^{3}$ A closer look at the composition of lending to different UK industries shows that capital inflows have a large positive effect on lending to the construction sector but not on lending to other industries. Furthermore, there is no evidence that funds from abroad which could be driven by push factors and may therefore not coincide with investment opportunities in the UK are directly channeled into the housing or the public sector. This also holds for the period prior to the financial

\footnotetext{
3"Other domestic financial institutions" in this context are UK resident banks and non-banks other than the UK bank which received the funds directly from abroad.
} 
crisis and seems to be at odds with the view that a global saving glut led to increased investment in ostensibly safe assets in advanced economies (Bernanke $(2005,2008)$ ). However, we cannot rule out that capital inflows into banks have an indirect effect on household lending. We find that capital inflows boost lending to other resident financial institutions and these institutions could channel the funds to the non-financial sectors of the economy, such as the household sector. Our evidence also suggests that much of the foreign capital flows back abroad. This is in line with the finding of Broner, Didier, Erce, and Schmukler (2013) that capital inflows by foreign agents coincide with capital outflows by domestic agents. We find that an increase in capital inflows equal to one percent of a bank's total liabilities is associated with an increase in the growth of credit to non-residents by around 1.3 percentage points.

Our finding that capital inflows are channeled to non-financial firms and to other domestic financial institutions is driven by the pre-crisis period. Capital inflows in the post-crisis period were not associated with higher domestic credit growth. The effect of capital inflows on lending to foreign counterparties for our post-crisis sample is more than twice the size of the effect for the pre-crisis sample. This suggests that after the crisis banks reallocated additional funds from abroad away from domestic lending and to non-resident lending. The insignificant effect of capital inflows on lending to the domestic sectors in the post-crisis period is also in line with a move towards market finance by the UK corporate sector (Financial Policy Committee (2017)) and a decline of the interconnectedness between banks after the crisis (Liu, Quiet, and Roth (2015)).

Our paper relates to several strands of literature. First, it contributes to the literature that has documented the relationship between capital inflows, credit booms and crises at the macrolevel. Cross-country evidence by Mendoza and Terrones (2012); Calderon and Kubota (2012); Lane and McQuade (2014); Elekdag and Wu (2013) shows that capital inflows are associated with credit booms. Several studies have highlighted the importance particularly of "other investment" flows in explaining credit booms (Igan and Tan (2017)) and financial vulnerabilities (Ghosh, Ostry, and Qureshi (2016)).

Second, our paper relates to the literature studying the effect of capital inflows on lending to corporates and households. Baskaya, Di Giovanni, Kalemli-Özcan, and Ulu (2017b) match bank 
and firm-level balance sheet data to show that higher global risk appetite as a driver of capital inflows boosts loan growth and reduces borrowing rates for corporates in Turkey. Igan and Tan (2017) find that non-FDI inflows are associated with credit booms in both the household and the corporate sectors. Their firm-level evidence suggests that "other investment" inflows are associated with faster credit growth for firms that rely heavily on external financing. Samarina and Bezemer (2016) argue that if foreign capital flows into economies with few investment opportunities, foreign funding substitutes for domestic bank lending to firms, with banks concentrating on household lending instead. They provide cross-country evidence showing that capital inflows into the nonbank sector are associated with lower shares of corporate credit on banks' balance sheets. Sá, Towbin, and Wieladek (2014) focus on the housing market instead. Their VAR estimations show that capital inflow shocks into OECD countries are associated with increases in credit to the private sector and residential investment, and with higher house prices.

Our paper is also related to the micro banking literature on the cross-border transmission of funding shocks during times of crisis. Schnabl (2012) exploits the Russian default of 1998 to examine how shocks to the balance sheets of banks that borrowed internationally affected firm lending in Peru. There is also an extensive literature studying the cross-border transmission of shocks to banks' funding and capital during the recent financial crisis and its effect on domestic credit markets (see for example Aiyar (2011); Cetorelli and Goldberg (2012); Popov and Udell (2010); Ongena, Peydro, and Van Horen (2015); Buch, Koch, and Koetter (2018)). The study most closely related to ours is Aiyar (2011). Aiyar (2011) examines the effect of the foreign funding shock to UK banks' balance sheets during the global financial crisis. The evidence provided by Aiyar (2011) suggests that this shock led to a reduction in lending to firms and other financial institutions but in line with our results, Aiyar (2011) does not find an effect on household credit.

Our contribution to the literature is twofold. First, our paper tracks foreign capital systematically across all sectors of the economy. This comprehensive assessment of the allocation of credit allows us to draw conclusions about sectors that may be prone to credit booms during inflow episodes and that may suffer from funding shortfalls when foreign capital is withdrawn. Second, we introduce a novel instrument for capital inflows. Our instrument allows us to study the effect of variation in funding from abroad during both crisis and normal times. We can therefore go beyond an analysis of the relationship between funding shortfalls and credit crunches during financial crises 
and also examine inflow surges and credit booms.

The remainder of the paper is structured as follows. Section 2 introduces our estimation methodology and explains the instrument. We discuss our data and show descriptive statistics in section 3. Our results are presented in section 4 and we discuss the robustness of our results in section 5. Section 6 concludes.

\section{Methodology}

\subsection{Regression setup}

To assess how inflows of foreign capital affect bank lending to different sectors, we estimate the following specification:

$$
\triangle \ln C_{b, t}=\beta \frac{\text { capital inflows }_{b, t}}{\text { total funding }_{b, t-1}}+\theta \text { demand }_{b, t}+\gamma \text { bank }_{b, t-1}+\delta_{t}+\nu_{b}+\epsilon_{b, t}
$$

where $\triangle \ln C_{b, t}$ is the change in the log of outstanding loans of bank $b$ to a sector between year-quarter $t$ and $(t-1)$, and capital inflows $b, t$ are inflows of foreign capital into bank $b$ over the quarter scaled by the bank's total liabilities in $(t-1)$. Demand $\mathbf{b}_{\mathbf{b}, \mathbf{t}}$ is a vector of time-varying controls for credit demand faced by bank $b$ and $\mathbf{b a n k}_{\mathbf{b}, \mathbf{t}-\mathbf{1}}$ is a vector of lagged balance sheet characteristics. $\nu_{b}$ and $\delta_{t}$ are bank and time fixed effects, respectively. Standard errors are clustered at the bank level to account for serial correlation within banks.

We run separate regressions for lending to the household sector, private non-financial corporations (PNFCs), other domestic financial institutions including both banks and non-banks, the

public sector, the domestic economy as a whole and for lending to non-residents. In the robustness section, we also show results using a broader definition of credit which encompasses both loans and security holdings.

The main variable of interest is inflows of foreign capital into a UK bank between $t$ and $t-1$ scaled by its total liabilities. The $\beta$-coefficient provides an estimate of the percentage change in outstanding credit to a sector in response to capital inflows equal to one percent of a bank's total 
liabilities.

Regressions of credit growth on capital inflows could suffer from endogeneity problems. For example, improvements in investment opportunities and higher expected future returns which are difficult to control for could attract foreign funding and simultaneously drive bank lending. Banks could also anticipate higher demand for credit and attract foreign deposits in order to meet this demand.

We address these endogeneity concerns in several ways. First, our regressions include yearquarter fixed effects to capture omitted variables that could affect both capital inflows and bank lending. The fixed effects capture macroeconomic developments such as business cycles, interest rate and exchange rate movements, or regulatory changes faced by all banks in our sample. Since we run separate regressions for lending to each sector of the economy, variation in sector-specific credit demand or in investment opportunities is also absorbed by the fixed effects. Second, we control explicitly for credit demand faced by individual banks from each sector given the composition of their loan portfolios. This is explained in section 2.3. Finally, we instrument for capital inflows using a Bartik shift-share instrument.

\subsection{Bartik instrument for capital inflows}

Granular data about the country of origin of foreign capital deposited with banks in the UK each quarter allow us to construct a Bartik shift-share instrument for capital inflows into a bank. Our instrument uses information about the historical distribution of funding from a foreign country across UK banks to allocate subsequent capital inflows from this country across recipient banks in the UK. This type of instrument has been widely used in the immigration literature to predict inflows of migrants into different cities of a host country based on historical settlement patterns of immigrants (Card (2005); Cortes (2008); Sá (2016)). The immigration literature exploits the persistence of the locational choices of migrants from different countries over time. Similarly, our instrument builds on the idea that there is persistence in foreign depositors' choices of UK banks when they deposit money in the UK. 
Formally, our instrument for inflows of foreign capital into bank $b$ in quarter $t$ is constructed as follows

$$
\text { capital inflows }_{b, t}=\sum_{c=1}^{C}\left(\text { share }_{c, b} * \text { capital inflows }_{c, t}\right)
$$

where $t>2000 Q 4$ and

$$
\text { share }_{c, b}=\frac{1}{12} \sum_{t=1}^{T=12} \frac{\text { foreign deposits } c, b, t}{\text { foreign deposits }_{c, t}}
$$

where $1998 Q 1 \leq t \leq 2000 Q 4$.

Thus, calculating the instrument involves three steps. First, we calculate the share $c, b$, i.e. the historical share of country $c$ 's total deposits in the UK that is deposited with bank $b$. Since the ratio of foreign capital deposited with a bank may vary from quarter to quarter, we average the ratio over an initial period which we define as the first three years of our sample period i.e. the 12 quarters from 1998Q1 to 2000Q4. In a second step, we multiply the share $c_{c, b}$ during the initial period with total inflows of foreign deposits from country $c$ into the UK banking sector during quarter $t$ in later years. ${ }^{4}$ Thus, the instrument uses the historical distribution of the stock of foreign deposits from some country $c$ across UK banks to allocate capital inflows from $c$ in subsequent quarters across UK banks. Finally, we obtain a measure of the aggregate capital inflows into bank $b$ in quarter $t$ by summing across capital inflows from all countries $c$.

The initial share has predictive power for the subsequent allocation of foreign funds across UK-resident banks due to branching networks of particular UK banks in certain foreign countries which may induce investors abroad to choose these UK banks over others, and due to sticky relationships between foreign depositors and their banks of choice in the UK. The persistence of historical bank-depositor relationships is also explained by global group structures which facilitate intragroup flows between entities of the same group operating both abroad and in the UK. Positive and significant coefficients from first stage regressions for equation (1) confirm that our instrument is relevant (Table 2). The Kleibergen-Paap first stage F-statistics in our IV regressions are above the ruleof-thumb value of 10 and point to a strong instrument (Staiger and Stock (1997); Stock and Yogo

\footnotetext{
${ }^{4}$ Note that the initial share and the inflows of country $c$ are calculated using stocks and flows of country c's total deposits with the UK banking sector, including with banks that are not part of our regressions sample.
} 
(2002)).

The validity of the capital flow instrument rests on the assumption that the factors determining the foreign investors' choice to deposit their capital with bank $b$ rather than bank $b$ ' during the initial period 1998Q1-2000Q4 are uncorrelated with differences in loan growth of bank $b$ and $b^{\prime}$ in subsequent quarters. If this exclusion restriction holds, the historical distribution of a country's deposits across UK banks only influences lending growth of these banks through its effect on current capital inflows. Furthermore, we require total inflows of foreign capital from country $c$ into the entire UK banking sector to be exogenous to the lending activity of an individual bank $b$. For example, differential shocks in credit demand of a particular sector faced by a bank at time $t$ should be uncorrelated with the total inflow of capital from some country $c$. This assumption is plausible unless particular countries deposit only with one or very few UK banks so that the total inflows from some countries into the UK as a whole are equivalent to the inflows received by individual banks. This is not the case: On average, a country transacts with 36 financial institutions in the UK during each quarter. Large, advanced countries such as the United States transact with as many as 250 UK banking entities during a quarter. It therefore seems reasonable to assume that capital inflows from a particular country are driven by country-specific push factors and UK-wide pull factors which are not specific to the lending behaviour of individual banks in our sample.

\subsection{Controls for credit demand and bank characteristics}

In addition to including time fixed effects and instrumenting for capital inflows to capture a credit supply response, we also control directly for variation in credit demand faced by individual banks. By including the vector demand $\mathbf{b}_{\mathbf{b}, \mathbf{t}}$ in equation (1) we address concerns that banks facing higher credit demand could attract more capital inflows to meet this demand. As in Aiyar (2011) and Aiyar, Calomiris, and Wieladek (2014), our demand measures exploit differences in the sectoral composition of banks' loan portfolios. For each bank, we construct measures of loan demand by firms, the household sector, and the rest of the world by combining a bank's lagged exposure to a sector with a measure of activity growth for the sector. Banks with larger pre-determined exposures to a sector should experience more credit demand when activity in that sector picks up. The activity of the sector should be exogenous to lending by individual banks unless credit provision to a sector 
is dominated by particular banks.

To capture credit demand by businesses, we include the term

$$
z_{b, t}=\sum_{i=1}^{12} s_{b, t-4}^{i} e m p_{t}^{i}
$$

, where $s$ denotes the lagged share of bank $b$ 's outstanding credit to industry $i$ divided by the bank's total assets in $(t-4)$. This share is multiplied by employment growth $e m p_{t}^{i}$ in industry $i$ between $t$ and $(t-4)$. Exposures to businesses are broken down into twelve non-financial industries and corporate credit includes credit to both privately owned and public companies. We therefore capture the demand from PNFCs and some of the demand from the public sector. Employment growth serves as a proxy for the expansion of real activity in an industry.

We follow a similar approach to proxy for credit demand by non-residents and households. Since household debt in the UK is dominated by mortgages and house prices drive loan size (Cloyne, Huber, Ilzetzki, and Kleven (2017)), we proxy for credit demand of households by multiplying the share of household loans in banks' total assets with house price growth between $t$ and $(t-4)$. To capture foreign demand we multiply outstanding credit to non-residents of a bank as a share of total assets with world GDP growth. ${ }^{5}$

Bank $_{\mathbf{b}, \mathbf{t}}$ includes a set of balance sheet characteristics that could affect a bank's willingness or ability to rely on foreign funding to expand its loan portfolio and its preferences when lending to sectors with different risk-return and maturity profiles. As is standard in the literature, we control for bank size as measured by the log of total assets. We also control for the ratio of liquid assets to total assets to capture a bank's ability to adjust its balance sheet in times of stress. Finally, we include the leverage ratio as measured by the ratio of total liabilities to total assets and the share of core, domestic deposits in total liabilities to take account of the stability and cost of bank funding. Baskaya, Di Giovanni, Kalemli-Özcan, and Ulu (2017b) have shown that better capitalized banks with higher non-core liabilities increase credit supply more in response to capital inflows.

\footnotetext{
${ }^{5}$ To capture foreign demand we use world GDP growth rather than employment growth which is not available for the world. A suitable measure of loan demand by other financial institutions is difficult to find and is omitted here.
} 


\section{Data and descriptive statistics}

\subsection{Data sources and variable construction}

We use quarterly bank balance sheet information collected through the Bank of England's regulatory reporting forms. ${ }^{6}$ Data are sourced from different reporting forms and merged to construct a quarterly panel dataset for the period from 1998Q1 to 2016Q4. ${ }^{7}$ Although all financial institutions which are authorised to accept deposits in the UK report to the Bank of England, our sample does not cover the entire UK banking sector due to threshold requirements for reporting individual balance sheet items. Our sample only includes banks with relatively large external liabilities. This is because banks with external liabilities below $£ 300$ million are not required to report the detailed breakdown of their liabilities by counterparty country that we use to construct our instrument. Institutions which did not report this information for the years 1998Q1-2000Q4, the period over which the historical share of the instrument is calculated, and institutions which did not survive over the sample period are excluded from our sample. Finally, we exclude four banks which do not lend to the UK real economy. We end up with a sample of 59 deposit taking institutions. ${ }^{8}$ The major banks which account for the bulk of outstanding credit to the UK real economy are included in our sample.

Our dependent variable is the change in the log of a bank's outstanding loans to a sector at the end of the quarter. We distinguish between bank lending to the household sector, private nonfinancial companies, the public sector, other domestic financial institutions including both banks and non-banks such as pension funds or insurance companies, and lending to non-residents. ${ }^{9}$ Detailed balance sheet data on bank assets allow us to dissect lending to households and corporates further. We distinguish between different types of loans to households and examine the relationship between capital inflows and mortgages (i.e. "lending to individuals secured on dwellings"), credit card balances and other consumer credit separately. For a subset of the banks in our sample, we can compare

\footnotetext{
${ }^{6}$ More information on the reporting forms and the reporting requirements is available on the Bank of England's website. The bank-level data are confidential and access is restricted.

${ }^{7}$ See Table A.1 in the appendix.

${ }^{8} 44$ of the banks in our sample are foreign owned and 15 are domestically owned entities.

${ }^{9}$ Note that the balance sheet data are subject to changes in reporting requirements and institution changes. For example, securitized assets are only consistently included in the credit statistics as from 2010 when reporting requirements changed.
} 
the results of our lending regressions for the household sector with results using the growth rate of new loan approvals as the dependent variable. We examine information on the number of loans approved for house purchases, for remortgaging, and for other purposes. For corporates, we also present evidence on lending by industrial sector. We examine bank loans to firms by SIC 2007 industrial sectors.

Most of our analysis focuses on bank loans. In the robustness section, we also report results using a broader definition of bank credit which includes both loans and security holdings of banks. Our measure of securities consists of equity and debt securities. For the public sector, this includes holdings of government securities by UK banks. Data on holdings of securities issued by non-residents are not available and our robustness analysis therefore focuses on residents only.

The main variable of interest in our model are capital inflows. Capital inflows are obtained by taking the difference between banks' end-of-quarter external liability positions. Our data on external liabilities consist of foreign sight and time deposits and liabilities under sale and repurchase agreements. ${ }^{10}$ All capital flows are exchange rate adjusted. ${ }^{11}$

To construct our instrument for capital inflows we use detailed information on the breakdown of the external liabilities of each bank by counterparty country for all reporting banks in the UK. Thus, total capital inflows from a country (capital inflows $b, t$ in equation (2)) capture all capital inflows into UK-resident banks and are not limited to inflows into the 59 banks in the regression sample. Similarly, foreign deposits $c, t$, the denominator of the share $c, b$ in equation (2), captures all external liabilities of UK-resident banks and is not confined to the liabilities of our 59 banks.

More details on the construction of the time-varying balance sheet control variables are provided in Table A.1 in the appendix. We rely on various external data sources to capture activity in our sectoral credit demand measures. We obtain data on employment growth by industry and house price growth for the UK from the ONS. World GDP is obtained from the International Financial Statistics.

To limit the effect of outliers, we winsorize all variables below the first and above the 99th percentile. Observations with asset growth in excess of $100 \%$ are dropped to account for mergers

\footnotetext{
${ }^{10}$ This measure omits bonds issued by UK-resident banks because the breakdown of bond holdings by residence of the investor is not available.

${ }^{11}$ Foreign deposit stocks in sterling are converted into their original currency at the end of quarter exchange rate before calculating the change in the stock. The flow is then converted back into sterling using the average exchange rate over the quarter.
} 
and acquisitions. We report summary statistics of our variables in Table A.2 in the appendix.

\subsection{Banks' reliance on foreign funding}

UK banks rely heavily on funding from abroad. About half of the total liabilities of banks resident in the UK between 2001 and 2016 were foreign funded. This also reflects the role of the UK as a global financial centre and the presence of international banks in London. On average, external liabilities accounted for roughly a quarter of the total liabilities of domestically owned banks and for roughly $60 \%$ of the liabilities of foreign-owned banks. Reliance on foreign funding increased rapidly in the run-up to the financial crisis, peaked at around $55 \%$ of total liabilities in 2008 , fell in the post-crisis years and then stabilized at around $50 \%$.

The sensitivity of bank lending to movements in foreign funding is partly determined by banks' ability to offset shocks to their total funding base by adjusting their domestic funding. Banks could for example keep the size of the balance sheets relatively stable over time if inflows of foreign capital coincided with a reduction of domestic funding. In this case, we would not necessarily expect an expansion of banks' credit supply in response to capital inflows. Conversely, banks would not be forced to shrink their loan books following the withdrawal of foreign funding if they could make up for this shortfall by raising additional domestic funding.

To test for substitution effects between domestic and foreign funding, we adapt the methodology of Card (2005) and Cortes (2008):

$$
\triangle \ln \text { total funding } b, t=\beta \frac{\text { capital inflows } b, t}{\text { total funding } b, t-1}+\delta_{t}+\nu_{b}+\epsilon_{b, t}
$$

Without substitution effects, capital inflows would equal the change in total funding and $\beta$ would be one. If movements in capital inflows were exactly matched by offsetting movements in domestic liabilities we would expect a $\beta$-coefficient of zero.

The results in Table 1 suggest that there is some substitution between domestic and foreign funding but it is far from perfect: The $\beta$-coefficient of 0.4 indicates that for every ten pounds that 
UK-resident banks receive from abroad they reduce their domestic funding base by six pounds. This finding is mainly due to imperfect substitution between capital inflows from foreign banks and domestic funding (column (2)). The coefficient on inflows from non-banks abroad in column (3) is not significantly different from zero, suggesting that UK banks fully adjust their domestic funding base to offset funding shocks from foreign non-banks. Overall, these findings indicate that bank lending should respond to capital inflows although the response could be muted by a partial adjustment of banks' domestic funding base.

\subsection{Foreign funding and bank lending}

The findings of the previous section suggest that UK-resident banks partially adjust their domestic funding to offset the effect of capital inflows on their total liabilities. This could imply that the response of total lending to capital inflows is muted. However, the bank's allocation of credit across sectors could change even if an inflow of foreign capital into a bank is perfectly matched by a decrease in its domestic deposits. As the evidence in this section indicates, there is a relationship between the portfolio composition of banks' balance sheets and the split of their liabilities into foreign and domestic funding.

Figures 3 shows how the composition of banks' loan portfolios varies with their reliance on foreign deposits. The charts plot outstanding loans as a share of total assets and foreign deposits as a share of total liabilities averaged over the period 2001Q1-2016Q4 for each bank. As Figure 3a shows, banks which rely more on foreign funding tend to have more foreign assets and less domestic loans on their balance sheets. Figure 3b sheds light on the composition of banks' domestic loan portfolios. Banks with higher foreign funding shares tend to have slightly smaller corporate and much smaller household loan portfolios. In fact, outstanding household loans of almost all banks with foreign funding shares in excess of $50 \%$ of their total liabilities amount to less than $1 \%$ of their total assets. Outstanding credit to domestic financial institutions does not vary systematically with banks' share of external liabilities. Public sector loan portfolios tend to be small in comparison and are not shown here.

Figure 4 shows co-movements of capital inflows with net lending by sector. The capital inflows and net lending are aggregated for the 37 banks in our sample for which we have complete 
data in every quarter throughout 2001Q1-2016Q4. The chart highlights the strong co-movement between capital inflows and foreign lending during both inflow and outflow episodes. Lending to corporates also moves closely with inflows, especially in the pre-crisis period. Finally, there is some co-movement with lending to domestic financial institutions although this is less pronounced in the early 2000s. There is no apparent relationship between capital inflows and lending to households or the public sector.

\section{Results}

\subsection{Baseline results}

Table 2 presents the results from estimating specification (2) with loan growth for different sectors of the economy as the dependent variable. We find that an increase in capital inflows equal to one percent of a UK bank's total liabilities results in a 0.8 percentage point increase in its domestic credit growth (column 5). This is driven by lending to firms (column 1) and to other domestic financial institutions (column 4). A one percentage point increase of capital inflows as a share of liabilities is associated with a 1.3 percentage point increase in the growth rate of loans to nonresidents. The large coefficient for capital inflows in the foreign lending regressions in column (6) suggests that much of the foreign funding that is received by UK banks has a transitional character.

We do not find a significant effect of capital inflows on lending to the public sector (column 2) or to households (column 3). The latter suggests that excess funds from abroad which could not be allocated to domestic firms were not directly channeled into the UK household sector. It would seem prudent of banks not to use volatile, short-term funding from abroad to fund long-term mortgages at home. Of course, it is possible that household credit growth was indirectly boosted by capital inflows: The bank which initially received the capital inflows could lend the funds to another bank in the UK and this bank could provide credit to the household sector. Our evidence cannot shed light on these indirect effects of capital inflows on sectoral lending that arise if the bank which initially received the capital inflows passes the foreign funds on to other domestic financial institutions. Given the large effect of foreign capital on lending to other UK financial institutions 
shown in column (4) of Table 2, these indirect effects could be substantial.

OLS estimates for Table 2 are shown in the appendix (Table A.3). The coefficients are of similar magnitude than in the IV regressions and the effect of capital inflows is insignificant in the regressions for household and public sector lending.

\subsection{A closer look at lending to the household and the corporate sectors}

Our finding that capital inflows into banks do not drive lending to the household sector is surprising. In the UK, the large build-up of household debt in the run-up to the financial crisis which was mostly driven by mortgage lending coincided with rapid accumulation of gross and net external liabilities by banks. Furthermore, evidence by Sá (2016) and Badarinza and Ramadorai (2018) shows that foreign investment drove house price growth in the UK. This would imply a link with household credit growth if these flows had been intermediated by banks in the UK.

To confirm the findings of our household loan regressions, we also estimate the effect of capital inflows on different types of household credit and we test whether capital inflows drive household loan approvals. Columns (1) to (3) of Table 3 show that the effect of capital inflows on mortgage loan growth, credit card lending growth and other consumer credit growth is not significantly different from zero. We provide evidence on household loan approvals for the $18 \mathrm{UK}$ banks for which data on approvals are available in columns (4) to (6). We do not find a significant effect of capital inflows on growth rates of loan approvals for housing or remortgaging. Only the effect of capital inflows on approval rates of "other loans" is large and significant. The small size of many of these loans could explain why this finding is not mirrored by the consumer credit growth results in column (3). More aggregate measures of household debt are dominated by mortgage lending and the lack of a significant effect on this category drives overall results. Overall, these results support our previous finding that capital inflows do not drive lending to the household sector. As before, we cannot rule out that capital inflows have an indirect effect on household debt as foreign funds could be channeled through the domestic financial system before reaching the household sector.

Table 4 provides more detail on the positive relationship between capital inflows and lending to corporates that we have document in the previous section. We assess the effect of capital inflows 
on lending to each industrial sector in the UK, with the exception of the financial sector and the public administration and defence sectors. Our evidence suggests that only the construction sector benefits from capital inflows. The coefficient on capital inflows is large and significant: Our estimates suggest that an increase in capital inflows equal to one percent of total liabilities results in a 12 percentage point increase of credit growth to the construction industry. This is in line with anecdotal evidence that extending credit quickly to new borrowers, especially smaller companies, can be challenging, but that lending to large property developers can be scaled up relatively fast. The negative coefficient in column (9) suggests that capital inflows are associated with a slower rate of new lending relative to repayment in professional services and could point to a reallocation of credit between sectors. Lending to manufacturing and other UK sectors does not vary systematically with capital inflows into UK banks.

\subsection{Results for different sample periods and for capital inflows from different foreign counterparties}

In this section we explore whether capital inflows into UK-resident banks had a different effect in the pre and the post-crisis periods given that financing patterns of the real sector and financial regulation changed after the financial crisis. We also shed light on the effect of capital inflows from different types of foreign counterparties.

First, we test whether credit growth in response to capital inflows differs during the pre and the post-crisis period. Our sample for the pre-crisis period consists of the years 2001-2007 and our sample for the post-crisis period of the years 2011-2016. Our evidence for the pre-crisis period in Table 5 confirms our previous findings that capital inflows were associated with more lending to firms, domestic financial institutions and non-residents. For the post-crisis period we only find a relationship between foreign funding and lending to non-residents.

The finding that foreign funding does not drive corporate credit growth in the post-crisis period is in line with a general move towards market based finance in the UK. Since the crisis, nearly all net finance raised by private non-financial corporations has been through the issuance of tradable securities, and most of this through corporate bond issuance (Financial Policy Committee (2017)). Our estimates for lending to other domestic financial institutions are also in line with UK-wide trends 
of direct banking sector interconnectedness. As Liu, Quiet, and Roth (2015) show, banking sector interconnectedness grew rapidly in the run-up to the crisis but has been falling since, possibly due to a reduction in risk appetite and regulatory initiatives. This includes the tightening of limits for large exposures between global systemically important banks (G-SIBs) and the use of interconnectedness as one of the indicators for identifying G-SIBs which are subject to stricter regulation. Growth rates of UK banks' lending to and borrowing from other banks and financial institutions have mostly been negative since 2008.

Next, we test whether the lending behaviour of UK banks differs depending on whether the counterparty abroad is a bank or not. Flows from foreign banks are larger than flows from nonbanks and they drive total inflows into UK-resident banks. Flows from foreign banks are also more volatile and do not co-move with flows from non-banks, possibly because they are not driven by the same underlying factors. Given these differences in the timing and the characteristics of the flows, recipient banks in the UK may not deploy these funds in the same way. Table 6 shows results from estimating equation (1) for inflows from non-resident banks only. In line with our findings for total capital inflows the results suggest that inflows from foreign banks are associated with lending to firms, financial institutions in the UK and with lending to non-residents. The magnitude of the coefficients is similar to the regressions for inflows from all foreign counterparties in Table 2. If we repeat the analysis for flows from non-banks we do not find a significant effect on credit growth. This suggests that the sensitivity of credit growth to capital inflows is mostly driven by bank-to-bank flows.

\section{Robustness}

In this section, we test the sensitivity of our instrumental variable results to a lengthening of the time horizon over which the share $c, b$, i.e. the historical distribution of foreign deposits from a country across UK-resident banks, is calculated. We also show evidence using a broader definition of credit growth based on both loans and security holdings.

The share of foreign deposits from a country that are deposited with bank b in the UK determines how the instrument allocates subsequent capital inflows from that country. The instrument 
used in the IV regressions thus far is based on a share $c, b$ which is calculated for the period from 1998Q1-2000Q4, as defined in equation (2). Since capital inflows that are deposited with UK banks vary over time, also due to changes in countries' relative economic strength and financial openness, we experimented with different horizons over which foreign deposit shares are calculated. The results in Table 7 show that estimates are robust to a lengthening of the share horizon to a five year period, from 1998Q1 to 2002Q4.

In Table 8, we provide evidence using credit growth based on both loans and security holdings as a dependent variable. This broader measure is available for funding of firms, the public sector and other domestic financial institutions. UK banks' security holdings are particularly large relative to loans for the public sector. The insignificant coefficient in column (2) suggests that capital inflows do not have an effect on bank lending to the public sector even when government bond holdings are taken into account. The effect of capital inflows on corporate loans turns insignificant when we use this broader measure of credit growth but the benchmark finding that capital inflows boost credit growth for other domestic financial institutions is confirmed.

\section{Conclusion}

In this paper, we trace out the path of foreign capital to the individual sectors of the UK economy. We assess where banks that are recipients of large amounts of foreign funding channel foreign capital using a novel instrument for capital inflows. Our results suggest that capital inflows have a significant positive effect on domestic credit growth despite the fact that banks cushion foreign funding shocks by adjusting their domestic funding base and channel funds back to foreign counterparties. Our evidence reveals that capital inflows into banks drive lending to the corporate sector and to other domestic financial institutions. The finding that foreign capital flows to the corporate sector is due to bank lending to the construction industry.

We do not find a significant effect of capital inflows on direct lending to the public sector or households. However, we cannot rule out that lending to these sectors is indirectly driven by foreign capital. Banks which are the initial recipients of foreign funding pass the funds on to other domestic financial institutions and these institutions could channel the funds to non-financial sectors. 
Our finding that capital inflows boost domestic credit growth is driven by the pre-crisis period. In the post-crisis period, the effect of capital inflows on lending to non-residents increases and the effect on domestic lending turns insignificant. In line with a move towards market finance by corporates and a decline in the interconnectedness of financial institutions, we do not find a relationship between capital inflows and bank lending to corporates or other domestic financial institutions in the years after the financial crisis. 


\section{References}

Aiyar, S., 2011. How did the crisis in international funding markets affect bank lending ? Balance sheet evidence from the United Kingdom. Bank of England Working Papers (424).

Aiyar, S., Calomiris, C., Wieladek, T., 2014. Does macro-prudential regulation leak ? Evidence from a UK policy experiment. Journal of Money, Credit and Banking 46 (1), 181-214.

Albertazzi, U., Bottero, M., 2014. Foreign bank lending: evidence from the global financial crisis. Journal of International Economics 92, 22-35.

Alfaro, L., Kalemli-Ozcan, S., Volosovych, V., 2008. Why doesn't capital flow from rich to poor countries? An empirical investigation. The Review of Economics and Statistics 90 (2), 347-368.

Allen, F., Beck, T., Carletti, E., Lane, P., Schoenmaker, D., Wagner, W., 2011. Cross-border banking in Europe: implications for financial stability and macroeconomic policies. CEPR.

Badarinza, C., Ramadorai, T., 2018. Home away from home? Foreign demand and London house prices. Journal of Financial Economics 130 (3), 532-555.

Baskaya, Y., Di Giovanni, J., Kalemli-Özcan, Ş., Peydró, J.-L., Ulu, M., 2017a. Capital flows and the international credit channel. Journal of International Economics 108, 15-22.

Baskaya, Y., Di Giovanni, J., Kalemli-Özcan, Ş., Ulu, M., 2017b. International spillovers and local credit cycles. NBER Working Papers (23149).

Bernanke, B., 2005. Remarks by Governor Ben Bernanke at the Sandridge lecture, Virginia Association of Economics, Richmond, Virginia.

Bernanke, B., 2008. Remarks by Chairman Ben Bernanke at the International Monetary Conference, Barcelona, Spain.

Bertaut, C., Pounder, L., Coonan, J., 2009. The financial crisis and US cross-border financial flows. Federal Reserve Bulletin, 147.

Blanchard, O., Ostry, J., Ghosh, A., Chamon, M., 2016. Capital flows: expansionary or contractionary? American Economic Review 106 (5), 565-69.

Bremus, F., Neugebauer, K., 2018. Reduced cross-border lending and financing costs of SMEs. Journal of International Money and Finance 80, 35-58.

Broner, F., Didier, T., Erce, A., Schmukler, S., 2013. Gross capital flows: Dynamics and crises. Journal of Monetary Economics 60, 113-133.

Buch, C., Koch, C., Koetter, M., 2018. Crises and rescues: liquidity transmission through global Banks. International Journal of Central Banking 14 (4), 187-228. 
Calderon, C., Kubota, M., 2012. Gross inflows gone wild: gross capital inflows, credit booms and crises. No. 6270.

Card, D., 2005. Is the new immigration really so bad ? The Economic Journal 115 (507), 300-323.

Cerutti, E., Dagher, J., Dell'Ariccia, G., 2017. Housing finance and real-estate booms: A crosscountry perspective. Journal of Housing Economics 38, 1-13.

Cetorelli, N., Goldberg, L., 2012. Liquidity management of US global banks: Internal capital markets in the great recession. Journal of International Economics 88 (2), 299-311.

Chow, H. K., Xie, T., 2016. Are House Prices Driven by Capital Flows ? Evidence from Singapore. Journal of International Commerce, Economics and Policy 7 (1650006).

Cloyne, J., Huber, K., Ilzetzki, E., Kleven, H., 2017. The effect of house prices on household borrowing: a new approach. Working Paper 23861, National Bureau of Economic Research.

Cortes, P., 2008. The effect of low-skilled immigration on US prices: Evidence from CPI data. Journal of Political Economy 116 (3), 381-422.

De Haas, R., Ferreira, D., Taci, A., 2010. What determines the composition of banks' loan portfolios ? Evidence from transition countries. Journal of Banking and Finance 34 (2), 388-398.

De Haas, R., Van Horen, N., 2013. Running for the exit ? International bank lending during a financial crisis. The Review of Financial Studies 26 (1), 244-285.

De Haas, R., Van Lelyveld, I., 2014. Multinational banks and the global financial crisis: Weathering the perfect storm ? Journal of Money, Credit and Banking 46 (1), 333-364.

Elekdag, S., Wu, Y., 2013. Rapid credit growth in emerging markets: Boon or boom-bust ? Journal of Emerging Markets Finance and Trade 49 (5), 45-62.

Financial Policy Committee, B. o. E., 2017. Financial Stability Report. Financial Stability Report (42).

Fratzscher, M., 2012. Capital flows, push versus pull factors and the global financial crisis. Journal of International Economics 88 (2), 341-356.

Ghosh, A., Ostry, J., Qureshi, M., 2016. When do capital inflow surges end in tears ? American Economic Review 106 (5), 581-85.

Hernández, L., Landerretche, O., et al., 2002. Capital inflows, credit booms, and macroeconomic vulnerability: the cross-country experience. Banking, Financial Integration, and International Crises, Central Bank of Chile Santiago, Chile, 199-233. 
Hoffmann, M., Stewen, I., 2019. Holes in the Dike: The global savings glut, U.S. house prices and the long shadow of banking deregulation. Journal of the European Economic Association, forthcoming.

Hoggarth, G., Jung, C., Reinhardt, D., 2016. Capital inflows - the good, the bad and the bubbly. Financial Stability Papers (40).

Igan, D., Tan, Z., 2017. Capital inflows, credit growth, and financial systems. Journal of Emerging Markets Finance and Trade 53 (12), 2649-2671.

Jansen, J., 2003. What do capital inflows do ? Dissecting the transmission mechanism for Thailand, 1980-1996. Journal of Macroeconomics 25 (4), 457-480.

Jiménez, G., Ongena, S., Peydró, J.-L., Saurina, J., 2012. Credit supply and monetary policy: Identifying the bank balance-sheet channel with loan applications. American Economic Review $102(5), 2301-26$.

Jiménez, G., Ongena, S., Peydró, J.-L., Saurina, J., 2014. Hazardous times for monetary policy: What do twenty-three million bank loans say about the effects of monetary policy on credit risktaking? Econometrica 82 (2), 463-505.

Jiménez, G., Ongena, S., Peydró, J.-L., Saurina Salas, J., 2017. Do demand or supply factors drive bank credit, in good and crisis times? Barcelona GSE Working Paper Series (966).

Khwaja, A. I., Mian, A., 2008. Tracing the impact of bank liquidity shocks: Evidence from an emerging market. American Economic Review 98 (4), 1413-42.

Kim, S., Yang, D. Y., 2011. The impact of capital inflows on asset prices in emerging Asian economies: Is too much money chasing too little good ? Open Economies Review 22 (2), 293-315.

Lane, P., McQuade, P., 2014. Domestic credit growth and international capital flows. The Scandinavian Journal of Economics 116 (1), 218-252.

Liu, Z., Quiet, S., Roth, B., 2015. Banking sector interconnectedness: What is it, how can we measure it and why does it matter? Quarterly Bulletin, Bank of England (Q2/2015).

Mendoza, E., Terrones, M., 2012. An anatomy of credit booms and their demise. NBER Working Papers (18379).

Milesi-Ferretti, G.-M., Tille, C., 2011. The great retrenchment: International capital flows during the global financial crisis. Economic Policy 26 (66), 289-346.

Morais, B., Peydró, J.-L., Roldán-Peña, J., Ruiz-Ortega, C., 2019. The international bank lending channel of monetary policy rates and QE: Credit supply, reach-for-yield, and real effects. The Journal of Finance 74 (1), 55-90. 
Noth, F., Busch, M. O., 2017. Banking globalization, local lending, and labor market effects: Microlevel evidence from Brazil. BOFIT discussion papers (11/2017).

Olaberría, E., 2012. Capital inflows and booms in assets prices: Evidence from a panel of countries. No. 675. Central Bank of Chile.

Ongena, S., Peydro, J.-L., Van Horen, N., 2015. Shocks abroad, pain at home ? bank-firm-level evidence on the international transmission of financial shocks. IMF Economic Review 63 (4), 698-750.

Ongena, S., Smith, D., 2001. The duration of bank relationships. Journal of Financial Economics $61(3), 449-475$.

Papaioannou, E., 2009. What drives international financial flows ? Politics, institutions and other determinants. Journal of Development Economics 88 (2), 269-281.

Peek, J., Rosengren, E., 2000. Collateral damage: Effects of the Japanese bank crisis on real activity in the United States. American Economic Review 90 (1), 30-45.

Phylaktis, K., Banti, C., 2016. Cross-border bank flows, funding liquidity and house prices. Unpublished.

Popov, A., Udell, G., 2010. Cross-border banking and the international transmission of financial distress during the crisis of 2007-2008. ECB Working Papers (1203).

Popov, A., Van Horen, N., 2014. Exporting sovereign stress: Evidence from syndicated bank lending during the euro area sovereign debt crisis. Review of Finance 19 (5), 1825-1866.

Sá, F., 2016. The effect of foreign investors on local housing markets: Evidence from the UK. CEPR Discussion Paper (DP11658).

Sá, F., Towbin, P., Wieladek, T., 2014. Capital inflows, financial structure and housing booms. Journal of the European Economic Association 12 (2), 522-546.

Samarina, A., Bezemer, D., 2016. Do capital flows change domestic credit allocation? Journal of International Money and Finance 62, 98-121.

Schnabl, P., 2012. The international transmission of bank liquidity shocks: Evidence from an emerging market. The Journal of Finance 67 (3), 897-932.

Staiger, D., Stock, J., 1997. Instrumental variables regression with weak instruments. Econometrica 65 (3), 557-586.

Stock, J., Yogo, M., 2002. Testing for weak instruments in linear IV regression. NBER Working Papers (284). 
Taguchi, H., Sahoo, P., Nataraj, G., 2015. Capital flows and asset prices: Empirical evidence from emerging and developing economies. Journal of International Economics 141, 1-14.

Tillmann, P., 2013. Capital inflows and asset prices: Evidence from emerging Asia. Journal of Banking and Finance 37 (3), 717-729.

Yiu, M., Sahminan, S., 2015. Global liquidity, capital inflows and house prices in ASEAN economies. HKIMR Working Paper (14/2015). 
Figure 1

External Assets and Liabilities of UK Financial Institutions

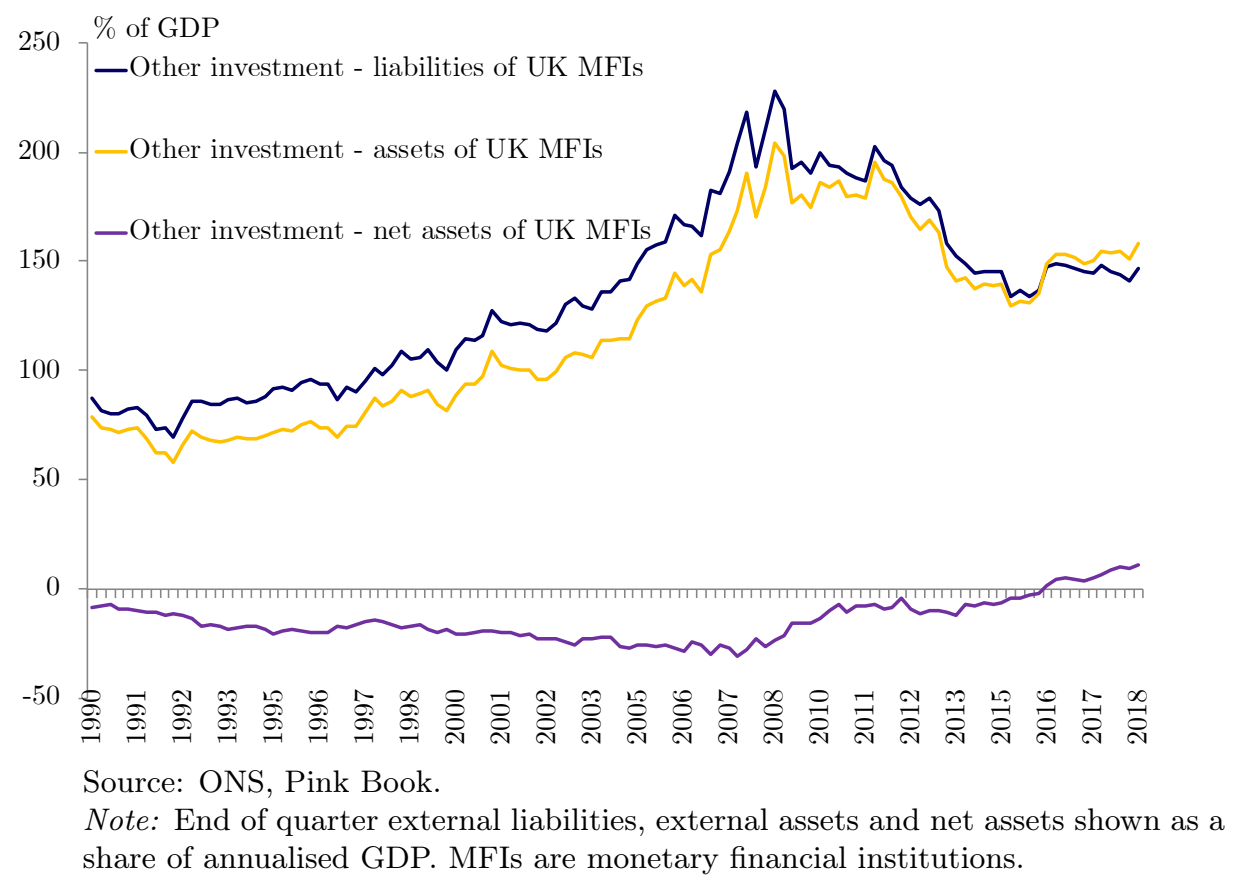

Figure 2

Gross Other Investment Inflows into UK Financial Institutions

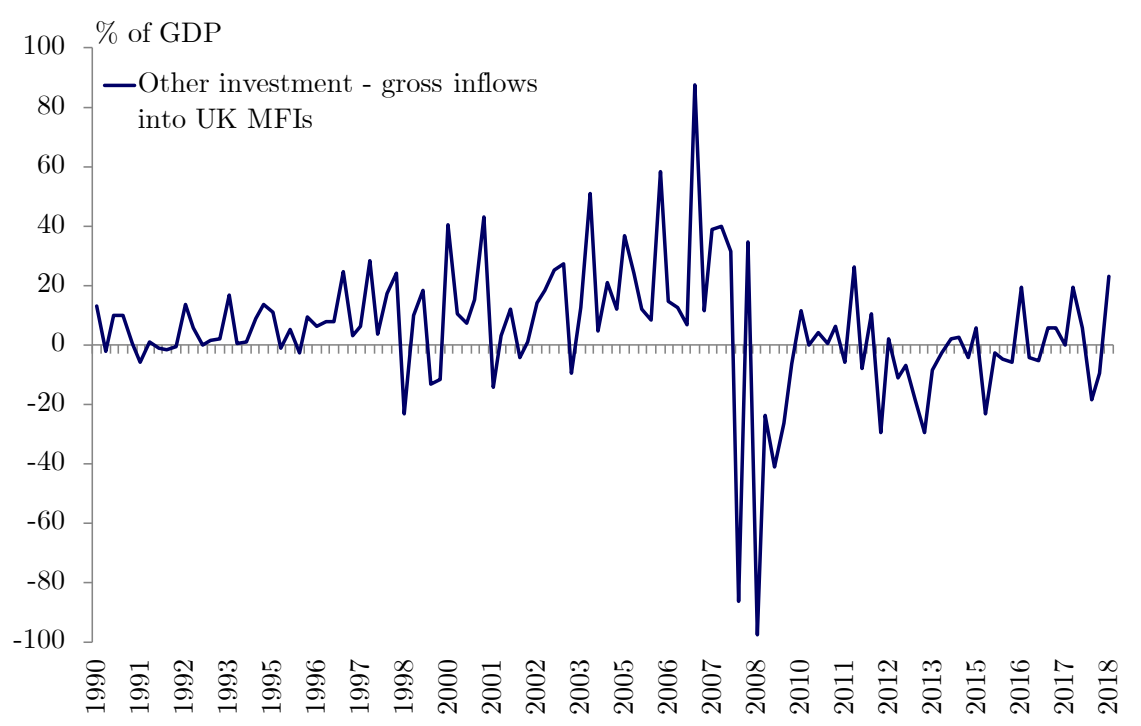

Source: ONS Pink Book.

Note: Quarterly other investment inflows shown as a share of quarterly GDP. 
Figure 3

Foreign Funding and the Composition of Banks' Loan Portfolios

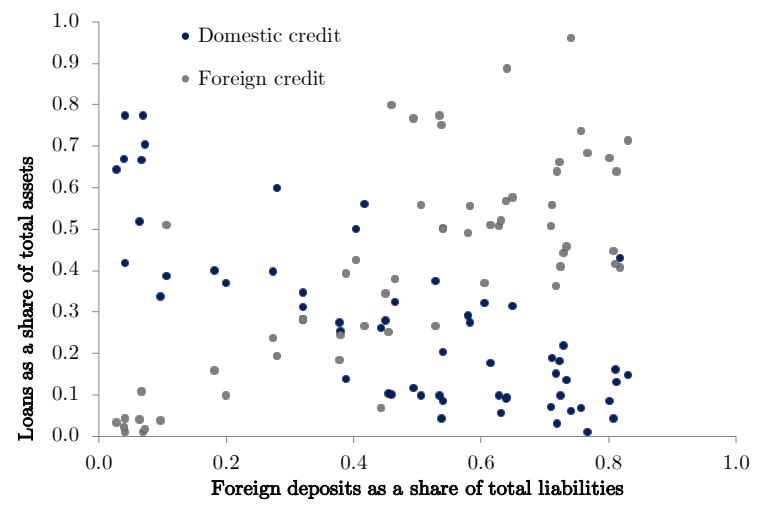

(a)

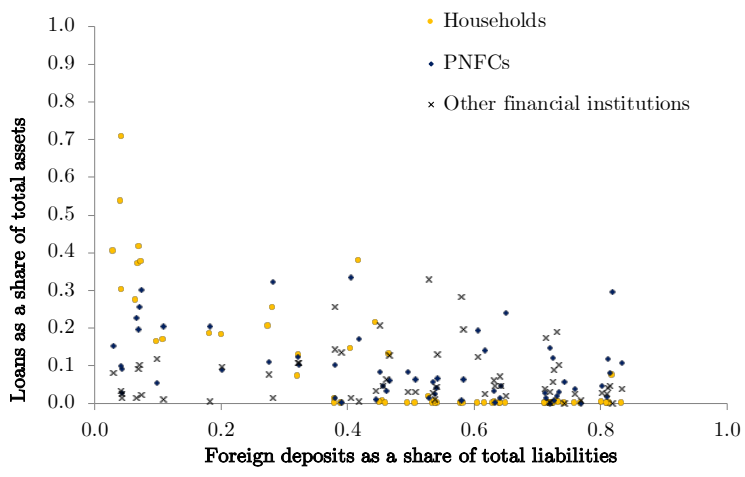

(b)

Note: Bank loans as a share of total assets and foreign deposits as a share of total liabilities averaged over the period 2001Q1-2016Q4 across all banks.

Figure 4

Co-movements of Capital Inflows and Lending by Sector

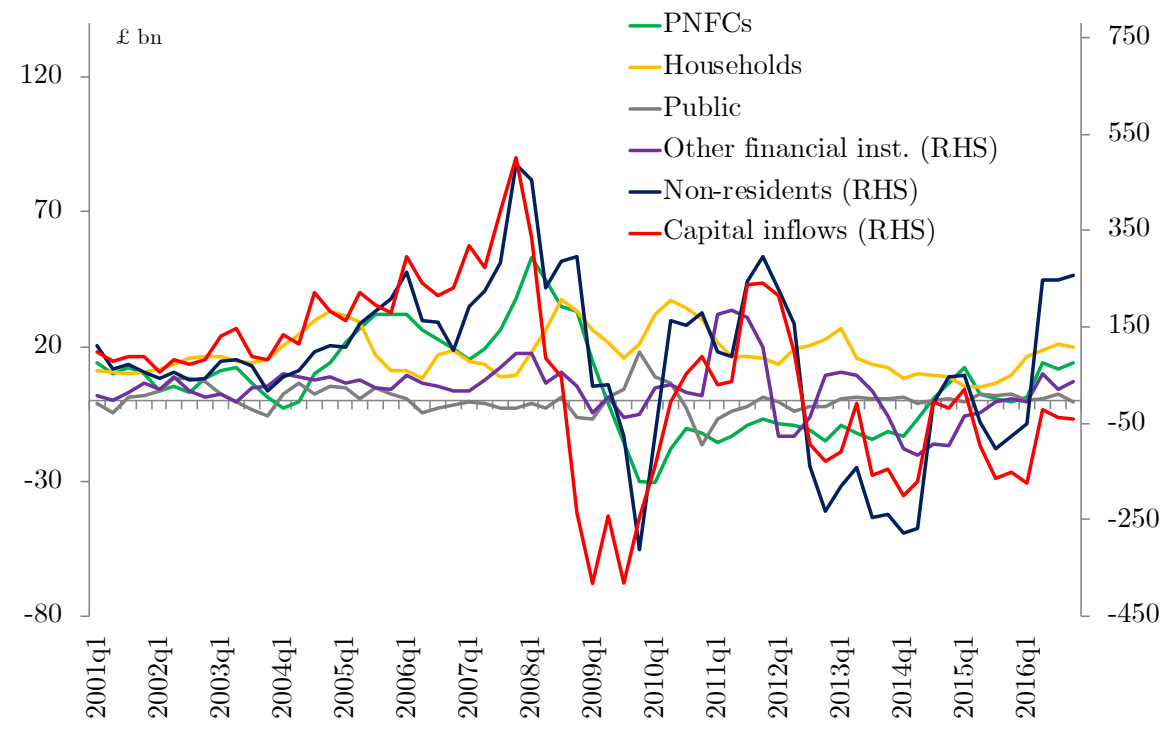

Note: Annualised flows aggregated for the 37 banks for which loans for each sector are available in every quarter without gaps. 
Table 1

Substitution between Domestic and Foreign Funding

\begin{tabular}{lccc}
\hline & $\begin{array}{c}\text { Change log } \\
\text { total funding }\end{array}$ & $\begin{array}{c}\text { Change log } \\
\text { total funding }\end{array}$ & $\begin{array}{c}\text { Change log } \\
\text { total funding }\end{array}$ \\
\cline { 2 - 4 } & $(1)$ & $(2)$ & $(3)$ \\
\hline Inflows/Funding & $\begin{array}{c}0.365^{* * *} \\
(0.0463)\end{array}$ & & \\
Bank inflows/Funding & & $0.397^{* * *}$ & \\
Non-bank inflows/Funding & & $(0.05)$ & 0.166 \\
& & & $(0.111)$ \\
& & & yes \\
Year-quarter FE & yes & yes & yes \\
Bank FE & yes & yes & 3332 \\
Observations & 3332 & 3332 & 0.115 \\
R-squared & 0.147 & 0.145 & 59 \\
Number of banks & 59 & 59 & \\
\hline
\end{tabular}

Note: This table reports the results from estimating equation (4) for the period from 2001Q1 to 2016Q4. It shows the results from OLS regressions of the change log of banks' total liabilities between quarter $t$ and ( $t-1)$ on capital inflows over the quarter $\mathrm{t}$ divided by total liabilities in ( $\mathrm{t}-1)$. The explanatory variables are total capital inflows into UK bank b as a share of bank b's total liabilities (column 1), inflows from non-resident banks into UK bank b as a share of total liabilities of UK bank b (column 2) and inflows from non-resident non-banks into UK bank b as a share of total liabilities of UK bank b (column 3). Standard errors clustered by bank are shown in parentheses. ${ }^{*}, * *$ and *** indicate statistical significance at the $10 \%, 5 \%$ and $1 \%$ level, respectively. 
Table 2

\section{The Effect of Capital Inflows on Lending by Sector}

\begin{tabular}{|c|c|c|c|c|c|c|}
\hline & \multicolumn{6}{|c|}{ Change log loans to } \\
\hline & \multicolumn{5}{|c|}{ Residents } & \multirow{2}{*}{$\begin{array}{c}\text { Non-residents } \\
(6) \\
\end{array}$} \\
\hline & $\begin{array}{l}\text { PNFCs } \\
(1)\end{array}$ & $\begin{array}{c}\text { Households } \\
(2)\end{array}$ & $\begin{array}{c}\text { Public sector } \\
(3)\end{array}$ & $\begin{array}{c}\text { Financial inst. } \\
(4)\end{array}$ & $\begin{array}{c}\text { All residents } \\
(5)\end{array}$ & \\
\hline Inflows/Funding & $\begin{array}{c}0.744^{* *} \\
(0.367)\end{array}$ & $\begin{array}{l}-0.16 \\
(3.55)\end{array}$ & $\begin{array}{l}-1.112 \\
(3.364)\end{array}$ & $\begin{array}{c}1.417^{* * * *} \\
(0.472)\end{array}$ & $\begin{array}{c}0.783^{* *} \\
(0.332)\end{array}$ & $\begin{array}{c}1.273^{* * *} \\
(0.273)\end{array}$ \\
\hline Assets & $\begin{array}{l}0.018^{*} \\
(0.011)\end{array}$ & $\begin{array}{l}0.0001 \\
(0.062)\end{array}$ & $\begin{array}{l}-0.003 \\
(0.076)\end{array}$ & $\begin{array}{l}-0.019 \\
(0.015)\end{array}$ & $\begin{array}{l}-0.004 \\
(0.007)\end{array}$ & $\begin{array}{l}-0.002 \\
(0.007)\end{array}$ \\
\hline Core deposits & $\begin{array}{c}0.016 \\
(0.133)\end{array}$ & $\begin{array}{c}0.143 \\
(0.462)\end{array}$ & $\begin{array}{l}-0.322 \\
(0.487)\end{array}$ & $\begin{array}{l}-0.074 \\
(0.108)\end{array}$ & $\begin{array}{l}-0.061 \\
(0.055)\end{array}$ & $\begin{array}{c}-0.011 \\
(0.066\end{array}$ \\
\hline Liquid assets & $\begin{array}{c}0.01 \\
(0.044)\end{array}$ & $\begin{array}{c}0.166 \\
(0.297)\end{array}$ & $\begin{array}{l}-0.023 \\
(0.469)\end{array}$ & $\begin{array}{c}0.077 \\
(0.072)\end{array}$ & $\begin{array}{c}0.044 \\
(0.043)\end{array}$ & $\begin{array}{l}-0.043 \\
(0.029)\end{array}$ \\
\hline Leverage & $\begin{array}{c}-0.16 \\
(0.161)\end{array}$ & $\begin{array}{c}0.243 \\
(0.423)\end{array}$ & $\begin{array}{c}2.246^{* * * *} \\
(0.841)\end{array}$ & $\begin{array}{c}-0.239^{*} \\
(0.123)\end{array}$ & $\begin{array}{l}-0.066 \\
(0.088)\end{array}$ & $\begin{array}{c}0.222^{* * *} \\
(0.063)\end{array}$ \\
\hline Demand industry & $\begin{array}{l}-0.084 \\
(1.449)\end{array}$ & $\begin{array}{l}0.495 \\
(11.2)\end{array}$ & $\begin{array}{l}-16.99 \\
(14.63)\end{array}$ & $\begin{array}{l}-1.543 \\
(2.797)\end{array}$ & $\begin{array}{c}0.394 \\
(1.254)\end{array}$ & $\begin{array}{c}1.73 \\
(1.694)\end{array}$ \\
\hline Demand households & $\begin{array}{c}1.041^{* * *} \\
(0.275)\end{array}$ & $\begin{array}{l}2.614 \\
(2.09)\end{array}$ & $\begin{array}{l}-1.473 \\
(2.844)\end{array}$ & $\begin{array}{l}1.064^{*} \\
(0.565)\end{array}$ & $\begin{array}{c}0.619^{* *} \\
(0.283)\end{array}$ & $\begin{array}{c}0.363 \\
(0.291)\end{array}$ \\
\hline Demand world & $\begin{array}{c}0.246 \\
(0.705)\end{array}$ & $\begin{array}{r}-2.836 \\
(6.48)\end{array}$ & $\begin{array}{c}-19.75^{*} \\
(11.22)\end{array}$ & $\begin{array}{c}0.743 \\
(1.337)\end{array}$ & $\begin{array}{c}0.533 \\
(0.617)\end{array}$ & $\begin{array}{c}-1.723^{* * *} \\
(0.61)\end{array}$ \\
\hline Year-quarter FE & yes & yes & yes & yes & yes & yes \\
\hline Bank FE & yes & yes & yes & yes & yes & yes \\
\hline Observations & 3332 & 3332 & 3332 & 3332 & 3332 & 3332 \\
\hline R-squared & 0.001 & 0.020 & 0.032 & 0.021 & 0.049 & 0.279 \\
\hline Number of banks & 59 & 59 & 59 & 59 & 59 & 59 \\
\hline First stage coefficent & $\begin{array}{c}0.402^{* * *} \\
(0.062)\end{array}$ & $\begin{array}{c}0.402^{* * *} \\
(0.062)\end{array}$ & $\begin{array}{c}0.402^{* * *} \\
(0.062)\end{array}$ & $\begin{array}{c}0.402^{* * *} \\
(0.062)\end{array}$ & $\begin{array}{c}0.402^{* * *} \\
(0.062)\end{array}$ & $\begin{array}{c}0.402^{* * *} \\
(0.062)\end{array}$ \\
\hline F-stat & 42.72 & 42.72 & 42.72 & 42.72 & 42.72 & 42.72 \\
\hline
\end{tabular}

Note: This table reports the results from estimating equation (1) for the period from 2001Q1 to 2016Q4 using 2SLS. The dependent variables are the change log of loans to private non-financial corporations (column 1), households (column 2), the public sector (column 3), resident financial institutions (column 4), the sum of the loans to these four sectors (column 5) and the change log of loans to non-residents (column 6). All regressions use the instrument for capital inflows shown in equation (2). The coefficients for the first stage regressions and the corresponding standard errors are shown in the penultimate row. The last row shows the Kleibergen-Paap F-statistic. Standard errors clustered by bank are shown in parentheses. $*, * *$ and $* * *$ indicate statistical significance at the $10 \%, 5 \%$ and $1 \%$ level, respectively. 
Table 3

The Effect of Capital Inflows on Household Lending and Loan Approval Growth

\begin{tabular}{|c|c|c|c|c|c|c|c|}
\hline & \multicolumn{3}{|c|}{ Change log household loans for } & \multicolumn{4}{|c|}{ Change log household loan approvals for } \\
\hline & $\begin{array}{c}\text { House purchase } \\
(1)\end{array}$ & $\begin{array}{c}\text { Credit card } \\
(2)\end{array}$ & $\begin{array}{l}\text { Other } \\
(3)\end{array}$ & $\begin{array}{c}\text { House purchase } \\
(4)\end{array}$ & $\begin{array}{c}\text { Remortgaging } \\
(5) \\
\end{array}$ & $\begin{array}{l}\text { Other } \\
(6)\end{array}$ & $\begin{array}{c}\text { All approvals } \\
(7)\end{array}$ \\
\hline Inflows/Funding & $\begin{array}{c}0.151 \\
(0.257)\end{array}$ & $\begin{array}{c}0.048 \\
(0.048)\end{array}$ & $\begin{array}{c}1.132 \\
(1.988)\end{array}$ & $\begin{array}{c}0.288 \\
(0.969)\end{array}$ & $\begin{array}{l}-1.515 \\
(1.538)\end{array}$ & $\begin{array}{l}6.761^{* *} \\
(3.102)\end{array}$ & $\begin{array}{c}-0.365 \\
(0.7)\end{array}$ \\
\hline Assets & $\begin{array}{l}-0.012 \\
(0.009)\end{array}$ & $\begin{array}{l}-0.001 \\
(0.001)\end{array}$ & $\begin{array}{l}-0.074 \\
(0.062)\end{array}$ & $\begin{array}{c}-0.116^{* * *} \\
(0.03)\end{array}$ & $\begin{array}{c}-0.143^{* * *} \\
(0.042)\end{array}$ & $\begin{array}{l}-0.247 \\
(0.247)\end{array}$ & $\begin{array}{c}-0.120^{* * *} \\
(0.029)\end{array}$ \\
\hline Core deposits & $\begin{array}{l}-0.055 \\
(0.044)\end{array}$ & $\begin{array}{l}0.009 \\
(0.01)\end{array}$ & $\begin{array}{l}-0.053 \\
(0.204)\end{array}$ & $\begin{array}{c}0.061 \\
(0.150)\end{array}$ & $\begin{array}{c}0.022 \\
(0.146)\end{array}$ & $\begin{array}{l}1.185^{*} \\
(0.668)\end{array}$ & $\begin{array}{l}-0.044 \\
(0.139)\end{array}$ \\
\hline Liquid assets & $\begin{array}{l}-0.031 \\
(0.047)\end{array}$ & $\begin{array}{c}0.004 \\
(0.005)\end{array}$ & $\begin{array}{c}0.358 \\
(0.258)\end{array}$ & $\begin{array}{l}-0.014 \\
(0.123)\end{array}$ & $\begin{array}{c}0.041 \\
(0.185)\end{array}$ & $\begin{array}{l}1.605^{* *} \\
(0.645)\end{array}$ & $\begin{array}{l}-0.049 \\
(0.142)\end{array}$ \\
\hline Leverage & $\begin{array}{c}0.147^{* *} \\
(0.075)\end{array}$ & $\begin{array}{c}0.018 \\
(0.019)\end{array}$ & $\begin{array}{c}-0.06 \\
(0.393)\end{array}$ & $\begin{array}{l}-0.133 \\
(0.144)\end{array}$ & $\begin{array}{r}-0.228^{*} \\
(0.126)\end{array}$ & $\begin{array}{c}-2.322^{* * *} \\
(0.87)\end{array}$ & $\begin{array}{l}-0.133 \\
(0.108)\end{array}$ \\
\hline Demand industry & $\begin{array}{c}1.033 \\
(1.191)\end{array}$ & $\begin{array}{c}0.706^{* *} \\
(0.276)\end{array}$ & $\begin{array}{l}-2.872 \\
(5.879)\end{array}$ & $\begin{array}{c}1.571 \\
(4.619)\end{array}$ & $\begin{array}{l}-1.193 \\
(5.623)\end{array}$ & $\begin{array}{l}-24.11 \\
(15.36)\end{array}$ & $\begin{array}{c}0.507 \\
(4.179)\end{array}$ \\
\hline Demand households & $\begin{array}{c}0.646^{* *} \\
(0.27)\end{array}$ & $\begin{array}{c}0.252^{* * *} \\
-0.078\end{array}$ & $\begin{array}{c}4.026^{* * *} \\
(1.289)\end{array}$ & $\begin{array}{c}0.11 \\
(0.695)\end{array}$ & $\begin{array}{l}-0.461 \\
(1.163)\end{array}$ & $\begin{array}{c}3.573 \\
(3.278)\end{array}$ & $\begin{array}{l}-0.132 \\
(0.614)\end{array}$ \\
\hline Demand world & $\begin{array}{l}-0.048 \\
(0.819)\end{array}$ & $\begin{array}{c}0.089 \\
(0.125)\end{array}$ & $\begin{array}{l}-5.289 \\
(3.794)\end{array}$ & $\begin{array}{c}2.37 \\
(2.621)\end{array}$ & $\begin{array}{c}0.623 \\
(3.021)\end{array}$ & $\begin{array}{c}28.14^{* *} \\
(14.21)\end{array}$ & $\begin{array}{c}0.263 \\
(2.525)\end{array}$ \\
\hline Year-quarter FE & yes & yes & yes & yes & yes & yes & yes \\
\hline Bank FE & yes & yes & yes & yes & yes & yes & yes \\
\hline Observations & 3332 & 3332 & 3332 & 1025 & 1023 & 1007 & 1007 \\
\hline R-squared & 0.026 & 0.078 & 0.014 & 0.185 & 0.047 & 0.081 & 0.137 \\
\hline Number of banks & 59 & 59 & 59 & 18 & 18 & 18 & 18 \\
\hline F-stat & 42.72 & 42.72 & 42.72 & 12.2 & 12.2 & 11.92 & 11.92 \\
\hline
\end{tabular}

Note: This table reports the results from estimating equation (1) for the period from 2001Q1 to 2016Q4 using 2SLS.

The dependent variables are the change log of loans for house purchases (column 1), credit card balances (column 2), other household loans (column 3), and change log of loan approvals for house purchases (column 4), loan approvals for remortgaging (column 5), all other household loan approvals (column 6) and the change log of all household loan approvals (column 7). All regressions use the instrument for capital inflows shown in equation (2). The last row shows the Kleibergen-Paap F-statistic. Standard errors clustered by bank are shown in parentheses. ${ }^{*}, * *$ and $* * *$ indicate statistical significance at the $10 \%, 5 \%$ and $1 \%$ level, respectively. 


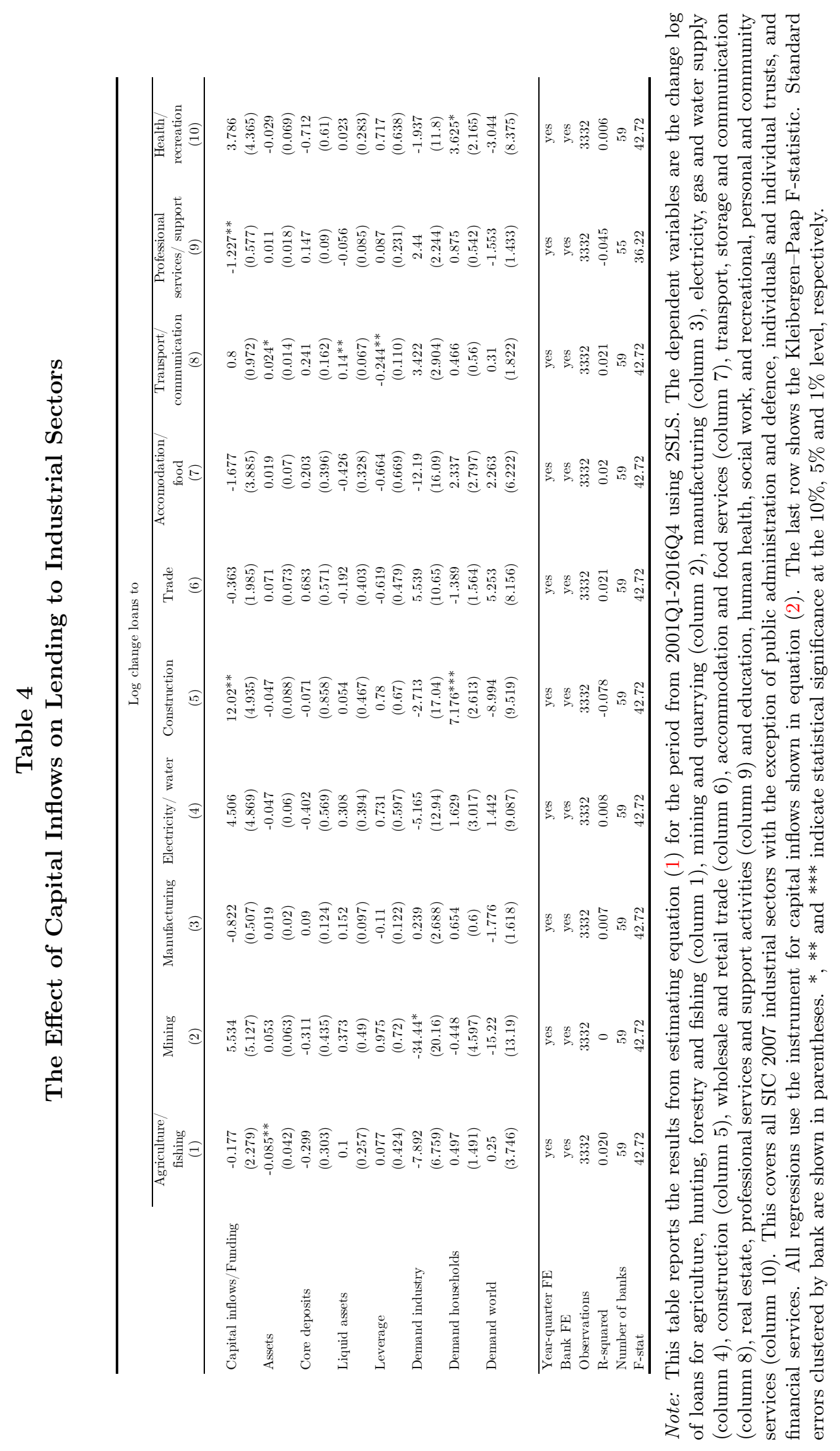


Table 5

The Effect of Capital Inflows in the Pre and the Post-Crisis Period

\begin{tabular}{|c|c|c|c|c|c|c|}
\hline & \multicolumn{6}{|c|}{ Log change loans to } \\
\hline & \multicolumn{5}{|c|}{ Residents } & \multirow{2}{*}{$\begin{array}{c}\text { Non-residents } \\
(6) \\
\end{array}$} \\
\hline & $\begin{array}{c}\text { PNFCs } \\
(1)\end{array}$ & $\begin{array}{c}\text { Households } \\
(2)\end{array}$ & $\begin{array}{c}\text { Public sector } \\
(3)\end{array}$ & $\begin{array}{c}\text { Financial inst. } \\
(4)\end{array}$ & $\begin{array}{c}\text { All residents } \\
(5)\end{array}$ & \\
\hline \multicolumn{7}{|l|}{ Panel A: Pre-crisis } \\
\hline Inflows/Funding & $\begin{array}{c}0.915^{* *} \\
(0.397)\end{array}$ & $\begin{array}{c}3.683 \\
(5.871)\end{array}$ & $\begin{array}{c}2.451 \\
(5.079)\end{array}$ & $\begin{array}{c}2.299 * * * \\
(0.771)\end{array}$ & $\begin{array}{c}1.079 * * * \\
(0.394)\end{array}$ & $\begin{array}{c}0.95 * * * \\
(0.295)\end{array}$ \\
\hline Controls & yes & yes & yes & yes & yes & yes \\
\hline Year-quarter FE & yes & yes & yes & yes & yes & yes \\
\hline Bank FE & yes & yes & yes & yes & yes & yes \\
\hline Observations & 1487 & 1487 & 1487 & 1487 & 1487 & 1487 \\
\hline R-squared & -0.025 & 0.006 & 0.037 & -0.028 & -0.003 & 0.216 \\
\hline Number of banks & 55 & 55 & 55 & 55 & 55 & 55 \\
\hline F-stat & 31.61 & 31.61 & 31.61 & 31.61 & 31.61 & 31.61 \\
\hline \multicolumn{7}{|l|}{ Panel B: Post-crisis } \\
\hline Inflows/Funding & $\begin{array}{c}0.779 \\
(0.571)\end{array}$ & $\begin{array}{c}0.795 \\
(5.381)\end{array}$ & $\begin{array}{l}-5.594 \\
(5.783)\end{array}$ & $\begin{array}{c}0.282 \\
(1.106)\end{array}$ & $\begin{array}{c}0.539 \\
(0.553)\end{array}$ & $\begin{array}{c}2.436^{* * *} \\
(0.576)\end{array}$ \\
\hline Controls & yes & yes & yes & yes & yes & yes \\
\hline Year-quarter FE & yes & yes & yes & yes & yes & yes \\
\hline Bank FE & yes & yes & yes & yes & yes & yes \\
\hline Observations & 1246 & 1246 & 1246 & 1246 & 1246 & 1246 \\
\hline R-squared & 0.003 & 0.017 & 0.022 & 0.074 & 0.093 & 0.111 \\
\hline Number of banks & 57 & 57 & 57 & 57 & 57 & 57 \\
\hline F-stat & 10.61 & 10.61 & 10.61 & 10.61 & 10.61 & 10.61 \\
\hline
\end{tabular}

Note: This table reports the results from estimating equation (1) for the period from 2001Q1-2007Q4 (panel A) and the period from 2011Q1-2016Q4 (panel B) using 2SLS. The dependent variables are change log of loans to private nonfinancial corporations (column 1), households (column 2), the public sector (column 3), resident financial institutions (column 4), the sum of the loans to these four sectors (column 5) and the change log of loans to non-residents (column 6). All regressions use the instrument for capital inflows shown in equation (2). The last row of each panel shows the Kleibergen-Paap F-statistic. Standard errors clustered by bank are shown in parentheses. *, ** and *** indicate statistical significance at the $10 \%, 5 \%$ and $1 \%$ level, respectively. 
Table 6

The Effect of Capital Inflows from Foreign Banks on Lending by Sector

\begin{tabular}{|c|c|c|c|c|c|c|}
\hline & \multicolumn{6}{|c|}{ Change log loans to } \\
\hline & \multicolumn{5}{|c|}{ Residents } & \multirow{2}{*}{$\begin{array}{c}\text { Non-residents } \\
(6)\end{array}$} \\
\hline & $\begin{array}{c}\text { PNFCs } \\
(1) \\
\end{array}$ & $\begin{array}{c}\text { Households } \\
(2) \\
\end{array}$ & $\begin{array}{c}\text { Public sector } \\
(3)\end{array}$ & $\begin{array}{c}\text { Financial inst. } \\
(4)\end{array}$ & $\begin{array}{c}\text { All residents } \\
(5)\end{array}$ & \\
\hline Bank inflows/Funding & $\begin{array}{c}0.883^{* * *} \\
(0.294)\end{array}$ & $\begin{array}{l}-0.567 \\
(3.166)\end{array}$ & $\begin{array}{c}-1.14 \\
(3.497)\end{array}$ & $\begin{array}{c}1.543^{* * *} \\
(0.429)\end{array}$ & $\begin{array}{c}1.005^{* * *} \\
(0.245)\end{array}$ & $\begin{array}{c}1.257^{* * *} \\
(0.228)\end{array}$ \\
\hline Assets & $\begin{array}{l}0.018^{*} \\
(0.011)\end{array}$ & $\begin{array}{c}-0.0002 \\
(0.062)\end{array}$ & $\begin{array}{l}-0.003 \\
(0.076)\end{array}$ & $\begin{array}{l}-0.018 \\
(0.015)\end{array}$ & $\begin{array}{l}-0.003 \\
(0.007)\end{array}$ & $\begin{array}{l}-0.002 \\
(0.008)\end{array}$ \\
\hline Core deposits & $\begin{array}{l}0.031 \\
(0.13)\end{array}$ & $\begin{array}{l}0.147 \\
(0.42)\end{array}$ & $\begin{array}{l}-0.347 \\
(0.478)\end{array}$ & $\begin{array}{c}-0.044 \\
(0.1)\end{array}$ & $\begin{array}{l}-0.047 \\
(0.048)\end{array}$ & $\begin{array}{c}0.019 \\
(0.058)\end{array}$ \\
\hline Liquid assets & $\begin{array}{c}0.025 \\
(0.045)\end{array}$ & $\begin{array}{c}0.146 \\
(0.285)\end{array}$ & $\begin{array}{l}-0.037 \\
(0.477)\end{array}$ & $\begin{array}{c}0.099 \\
(0.072)\end{array}$ & $\begin{array}{c}0.063 \\
(0.041)\end{array}$ & $\begin{array}{l}-0.029 \\
(0.032)\end{array}$ \\
\hline Leverage & $\begin{array}{l}-0.151 \\
(0.163)\end{array}$ & $\begin{array}{c}0.229 \\
(0.412)\end{array}$ & $\begin{array}{c}2.237^{* * *} \\
(0.854)\end{array}$ & $\begin{array}{c}-0.224^{*} \\
(0.127)\end{array}$ & $\begin{array}{l}-0.054 \\
(0.085)\end{array}$ & $\begin{array}{c}0.231^{* * *} * \\
(0.066)\end{array}$ \\
\hline Demand industry & $\begin{array}{c}0.145 \\
(1.409)\end{array}$ & $\begin{array}{c}0.41 \\
(11.05)\end{array}$ & $\begin{array}{l}-17.31 \\
(14.31)\end{array}$ & $\begin{array}{l}-1.119 \\
(2.912)\end{array}$ & $\begin{array}{c}0.643 \\
(1.288)\end{array}$ & $\begin{array}{c}2.099 \\
(1.737)\end{array}$ \\
\hline Demand households & $\begin{array}{c}1.071 * * * \\
(0.272)\end{array}$ & $\begin{array}{c}2.509 \\
(1.949)\end{array}$ & $\begin{array}{l}-1.47 \\
(2.97)\end{array}$ & $\begin{array}{c}1.084^{* *} \\
(0.535)\end{array}$ & $\begin{array}{l}0.67^{* *} \\
(0.287)\end{array}$ & $\begin{array}{c}0.347 \\
(0.343)\end{array}$ \\
\hline Demand world & $\begin{array}{c}0.097 \\
(0.726)\end{array}$ & $\begin{array}{l}-2.788 \\
(6.495)\end{array}$ & $\begin{array}{c}-19.54^{*} \\
(11.23)\end{array}$ & $\begin{array}{c}0.466 \\
(1.332)\end{array}$ & $\begin{array}{c}0.373 \\
(0.603)\end{array}$ & $\begin{array}{c}-1.967^{* * *} \\
(0.597)\end{array}$ \\
\hline Year-quarter FE & yes & yes & yes & yes & yes & yes \\
\hline Bank FE & yes & yes & yes & yes & yes & yes \\
\hline Observations & 3332 & 3332 & 3332 & 3332 & 3332 & 3332 \\
\hline R-squared & -0.011 & 0.019 & 0.033 & 0.022 & 0.04 & 0.201 \\
\hline Number of banks & 59 & 59 & 59 & 59 & 59 & 59 \\
\hline F-stat & 39.08 & 39.08 & 39.08 & 39.08 & 39.08 & 39.08 \\
\hline
\end{tabular}

Note: This table reports the results from estimating equation (1) for the period from 2001Q1 to 2016Q4 using 2SLS. The dependent variables are the change log of loans to private non-financial corporations (column 1), households (column 2), the public sector (column 3), resident financial institutions (column 4), the sum of the loans to these four sectors (column 5) and the change log of loans to non-residents (column 6). All regressions use the instrument for capital inflows as in equation (2) but the share is now calculated using deposits from foreign banks only and capital inflows from a country only include inflows from banks. The last row shows the Kleibergen-Paap F-statistic. Standard errors clustered by bank are shown in parentheses. $*, * *$ and $* * *$ indicate statistical significance at the $10 \%, 5 \%$ and $1 \%$ level, respectively. 
Table 7

The Effect of Capital Inflows on Lending using a Modified Instrument

\begin{tabular}{|c|c|c|c|c|c|c|}
\hline & \multicolumn{6}{|c|}{ Change log loans to } \\
\hline & \multicolumn{5}{|c|}{ Residents } & \multirow{2}{*}{$\begin{array}{c}\text { Non-residents } \\
(6) \\
\end{array}$} \\
\hline & $\begin{array}{c}\text { PNFCs } \\
(1) \\
\end{array}$ & $\begin{array}{c}\text { Households } \\
(2) \\
\end{array}$ & $\begin{array}{c}\text { Public sector } \\
(3) \\
\end{array}$ & $\begin{array}{c}\text { Financial inst. } \\
(4) \\
\end{array}$ & $\begin{array}{c}\text { All residents } \\
(5) \\
\end{array}$ & \\
\hline Inflows/Funding & $\begin{array}{c}0.756^{* *} \\
(0.366)\end{array}$ & $\begin{array}{l}-1.851 \\
(3.813)\end{array}$ & $\begin{array}{l}-0.462 \\
(3.248)\end{array}$ & $\begin{array}{c}1.507 * * * \\
(0.54)\end{array}$ & $\begin{array}{c}1.025^{* * *} \\
(0.375)\end{array}$ & $\begin{array}{c}1.276^{* * *} \\
(0.256)\end{array}$ \\
\hline Assets & $\begin{array}{c}0.018^{*} \\
(0.01)\end{array}$ & $\begin{array}{c}-0.0004 \\
(0.06)\end{array}$ & $\begin{array}{l}-0.003 \\
(0.077)\end{array}$ & $\begin{array}{l}-0.018 \\
(0.015)\end{array}$ & $\begin{array}{l}-0.004 \\
(0.007)\end{array}$ & $\begin{array}{l}-0.002 \\
(0.007)\end{array}$ \\
\hline Core deposits & $\begin{array}{c}0.016 \\
(0.134)\end{array}$ & $\begin{array}{c}0.213 \\
(0.488)\end{array}$ & $\begin{array}{l}-0.348 \\
(0.506)\end{array}$ & $\begin{array}{l}-0.078 \\
(0.111)\end{array}$ & $\begin{array}{c}-0.07 \\
(0.057)\end{array}$ & $\begin{array}{l}-0.011 \\
(0.067)\end{array}$ \\
\hline Liquid assets & $\begin{array}{c}0.01 \\
(0.044)\end{array}$ & $\begin{array}{c}0.113 \\
(0.309)\end{array}$ & $\begin{array}{l}-0.003 \\
(0.454)\end{array}$ & $\begin{array}{c}0.08 \\
(0.072)\end{array}$ & $\begin{array}{c}0.051 \\
(0.046)\end{array}$ & $\begin{array}{l}-0.043 \\
(0.029)\end{array}$ \\
\hline Leverage & $\begin{array}{c}-0.16 \\
(0.161)\end{array}$ & $\begin{array}{c}0.203 \\
(0.428)\end{array}$ & $\begin{array}{c}2.261^{* * *} \\
(0.838)\end{array}$ & $\begin{array}{c}-0.237^{*} \\
(0.125)\end{array}$ & $\begin{array}{l}-0.061 \\
(0.088)\end{array}$ & $\begin{array}{c}0.222^{* * *} \\
(0.063)\end{array}$ \\
\hline Demand industry & $\begin{array}{l}-0.086 \\
(1.455)\end{array}$ & $\begin{array}{c}0.831 \\
(11.04)\end{array}$ & $\begin{array}{l}-17.12 \\
(14.58)\end{array}$ & $\begin{array}{l}-1.561 \\
(2.821)\end{array}$ & $\begin{array}{c}0.346 \\
(1.286)\end{array}$ & $\begin{array}{c}1.729 \\
(1.695)\end{array}$ \\
\hline Demand households & $\begin{array}{c}1.045^{* * *} \\
(0.277)\end{array}$ & $\begin{array}{l}2.156 \\
(2.134)\end{array}$ & $\begin{array}{l}-1.297 \\
(2.879)\end{array}$ & $\begin{array}{l}1.088^{*} \\
(0.572)\end{array}$ & $\begin{array}{c}0.685^{* *} \\
(0.303)\end{array}$ & $\begin{array}{c}0.364 \\
(0.291)\end{array}$ \\
\hline Demand world & $\begin{array}{c}0.248 \\
(0.705)\end{array}$ & $\begin{array}{l}-3.086 \\
(6.624)\end{array}$ & $\begin{array}{c}-19.66^{*} \\
(11.17)\end{array}$ & $\begin{array}{c}0.757 \\
(1.333)\end{array}$ & $\begin{array}{l}0.569 \\
(0.62)\end{array}$ & $\begin{array}{c}-1.723^{* * *} \\
(0.607)\end{array}$ \\
\hline Year-quarter FE & yes & yes & yes & yes & yes & yes \\
\hline Bank FE & yes & yes & yes & yes & yes & yes \\
\hline Observations & 3332 & 3332 & 3332 & 3332 & 3332 & 3332 \\
\hline R-squared & -0.001 & 0.017 & 0.032 & 0.017 & 0.024 & 0.279 \\
\hline Number of banks & 59 & 59 & 59 & 59 & 59 & 59 \\
\hline F-stat & 36.50 & 36.50 & 36.50 & 36.50 & 36.50 & 36.50 \\
\hline
\end{tabular}

Note: This table reports the results from estimating equation (1) for the period from 2001Q1 to 2016Q4 using 2SLS. The dependent variables are the change log of loans to private non-financial corporations (column 1), households (column 2), the public sector (column 3), resident financial institutions (column 4), the sum of the loans to these four sectors (column 5) and the change log of loans to non-residents (column 6). All regressions use the instrument for capital inflows shown in equation (2) except that the share is now calculated for the period 1998Q1-2002Q4. The last row shows the Kleibergen-Paap F-statistic. Standard errors clustered by bank are shown in parentheses. *, ** and *** indicate statistical significance at the $10 \%, 5 \%$ and $1 \%$ level, respectively. 
Table 8

The Effect of Capital Inflows on Broad Credit Growth

\begin{tabular}{|c|c|c|c|}
\hline & \multicolumn{3}{|c|}{ Changelog loans and security holdings to } \\
\hline & $\begin{array}{c}\text { PNFCs } \\
(1)\end{array}$ & $\begin{array}{c}\text { Public sector } \\
(2) \\
\end{array}$ & $\begin{array}{c}\text { Financial inst. } \\
(3) \\
\end{array}$ \\
\hline Inflows/Funding & $\begin{array}{c}0.678 \\
(0.432)\end{array}$ & $\begin{array}{c}2.063 \\
(4.341)\end{array}$ & $\begin{array}{c}1.002^{* *} \\
(0.438)\end{array}$ \\
\hline Assets & $\begin{array}{c}0.026^{* *} \\
(0.01)\end{array}$ & $\begin{array}{c}0.05 \\
(0.062)\end{array}$ & $\begin{array}{l}-0.017 \\
(0.012)\end{array}$ \\
\hline Core deposits & $\begin{array}{l}-0.052 \\
(0.098)\end{array}$ & $\begin{array}{l}-0.065 \\
(0.727)\end{array}$ & $\begin{array}{l}-0.017 \\
(0.063)\end{array}$ \\
\hline Liquid assets & $\begin{array}{l}-0.003 \\
(0.049)\end{array}$ & $\begin{array}{l}-0.315 \\
(0.496)\end{array}$ & $\begin{array}{c}0.003 \\
(0.055)\end{array}$ \\
\hline Leverage & $\begin{array}{l}-0.086 \\
(0.104)\end{array}$ & $\begin{array}{c}1.455^{* *} \\
(0.702)\end{array}$ & $\begin{array}{l}-0.141 \\
(0.118)\end{array}$ \\
\hline Demand industry & $\begin{array}{l}0.942 \\
(1.43)\end{array}$ & $\begin{array}{l}-1.563 \\
(13.34)\end{array}$ & $\begin{array}{l}-0.814 \\
(2.533)\end{array}$ \\
\hline Demand households & $\begin{array}{c}1.214^{* * *} \\
(0.302)\end{array}$ & $\begin{array}{c}1.905 \\
(2.497)\end{array}$ & $\begin{array}{c}0.419 \\
(0.483)\end{array}$ \\
\hline Demand world & $\begin{array}{c}0.651 \\
(0.582)\end{array}$ & $\begin{array}{c}2.702 \\
(10.84)\end{array}$ & $\begin{array}{l}0.916 \\
(1.14)\end{array}$ \\
\hline Year-quarter FE & yes & yes & yes \\
\hline Bank FE & yes & yes & yes \\
\hline Observations & 3305 & 3250 & 3305 \\
\hline R-squared & 0.007 & 0.03 & 0.033 \\
\hline Number of banks & 59 & 59 & 59 \\
\hline F-stat & 41.19 & 39.31 & 38.17 \\
\hline
\end{tabular}

Note: This table reports the results from estimating equation (1) for the period from 2001Q1 to 2016Q4 using 2SLS. The dependent variables are the change log of loans and security holdings to private non-financial corporations (column 1), the public sector (column 2) and resident financial institutions (column 3). All regressions use the instrument for capital inflows shown in equation (2). The last row shows the Kleibergen-Paap F-statistic. Standard errors clustered by bank are shown in parentheses. ${ }^{*}, * *$ and $* * *$ indicate statistical significance at the $10 \%, 5 \%$ and $1 \%$ level, respectively. 
Table A.1

Variable Construction and Sources

\begin{tabular}{l} 
Variables \\
\hline Dependent variables \\
Growth of loans to PNFC sector \\
Growth of loans to household sector \\
Growth of loans to financial institutions \\
Growth of loans to public sector \\
Growth of loans to non-residents \\
Growth of loans for house purchases \\
Growth of loans for credit cards \\
Growth of loans for other household loans \\
Approval rate, loans for house purchases \\
Approval rate, loans for remortgage \\
Approval rate, other loans \\
Approval rate, all loans \\
Growth of loans and securities, PNFC sector \\
Growth of loans and securities, public sector \\
Growth of loans and securities, other domestic \\
financial institutions
\end{tabular}

financial institutions

\section{Capital inflows}

Capital inflows

Bank balance sheet controls

Total liabilities

Total assets

Core deposits

Liquid assets

Leverage
Change log of outstanding loans to PNFC sector

Change log of outstanding loans to household sector

Change log of outstanding loans to financial institutions

Change log of outstanding loans to public sector

Change log of outstanding loans to non-residents

Change log of outstanding mortgage loans

Change log of outstanding credit card balances

Change log of outstanding other household loans

Growth rate of loan approvals for house purchases

Growth rate of loan approvals for remortgaging

Growth rate of loan approvals for other advances

Growth rate of loan approvals for house purchases, remortgaging and other advances

Change log of outstanding loans to PNFC sector plus holdings of BE form PNFC securities

Change log of outstanding loans to public sector plus holdings of government bonds

Change log of outstanding loans to financial institutions plus holdings of securities issued by financial institutions

Change of non-resident sight and time deposits and liabilities under sale and repurchase agreements

Total assets minus capital

Total assets

Sight and time deposits of UK residents as a share of total liabilities

Sum of cash holdings, government bond holdings and market loans as a share of total assets

Liabilities as a share of total assets
BE form

$\mathrm{BE}$ form

AL form

BT form

BT form

BE form

$\mathrm{BE}$ form

BE form

IS form

IS form

IS form

IS form

BT form

AL \& BE forms 
Table A.2

Summary Statistics

\begin{tabular}{lrrr}
\hline & Mean & $\begin{array}{c}\text { Median } \\
(1)\end{array}$ & $\begin{array}{c}\text { St.dev. } \\
(2)\end{array}$ \\
\hline Change log of loans to & & & \\
PNFCs & 0.006 & 0 & 0.224 \\
Households & -0.034 & 0 & 2.167 \\
Public sector & -0.007 & 0 & 3.699 \\
Financial inst. & 0.022 & 0 & 0.468 \\
All residents & 0.017 & 0.008 & 0.231 \\
Nonresidents & 0.014 & 0.008 & 0.211 \\
& & & \\
Capital inflows & & & \\
Inflows/Funding & 0.009 & 0.001 & 0.085 \\
Instrument & 0.006 & 0.002 & 0.036 \\
& & & \\
Bank balance sheet controls & & \\
Log of assets & 10.212 & 9.952 & 1.476 \\
Core deposit ratio & 0.247 & 0.144 & 0.249 \\
Liquid asset ratio & 0.391 & 0.364 & 0.228 \\
Leverage ratio & 0.926 & 0.958 & 0.1 \\
& & & \\
Demand measures for & & & 0.003 \\
Industry & 0.001 & 0.0002 & 0.011 \\
Households & 0.006 & 0 & 0.014 \\
World & 0.015 & 0.014 \\
\hline
\end{tabular}

Note: This table shows the sample averages, medians and standard deviations of the main variables used in our analysis for the period 2001Q1-2016Q4. The dependent variables are the change log of loans to private non-financial corporations (PNFCs), households, the public sector, resident financial institutions, loans to all residents and loans to non-residents. The main explanatory variable is the ratio of capital inflows between quarter $t$ and $(\mathrm{t}-1)$ and bank liabilities in ( $t-1)$. We instrument for capital inflows as shown in equation (2) and scale the measure by bank liabilities in (t-1). Bank balance sheet variables are the log of total assets, the ratio of core deposits to liabilities, the ratio of liquid assets to total assets and the ratio of total liabilities to total assets. The construction of the demand measures is explained in section 2.3 . 
Table A.3

Baseline Results estimated using OLS

\begin{tabular}{|c|c|c|c|c|c|c|}
\hline & \multicolumn{6}{|c|}{ Log change loans to } \\
\hline & \multicolumn{5}{|c|}{ Residents } & \multirow{2}{*}{$\begin{array}{c}\text { Non-residents } \\
(6) \\
\end{array}$} \\
\hline & $\begin{array}{c}\text { PNFCs } \\
(1)\end{array}$ & $\begin{array}{l}\text { Households } \\
\text { (2) }\end{array}$ & $\begin{array}{c}\text { Public sector } \\
\text { (3) }\end{array}$ & $\begin{array}{c}\text { Financial inst. } \\
(4)\end{array}$ & $\begin{array}{c}\text { All residents } \\
(5)\end{array}$ & \\
\hline Inflows/Funding & $\begin{array}{l}0.17^{* *} \\
(0.072)\end{array}$ & $\begin{array}{l}-0.559 \\
(0.516)\end{array}$ & $\begin{array}{c}0.387 \\
(0.814)\end{array}$ & $\begin{array}{c}0.662^{* * *} \\
(0.148)\end{array}$ & $\begin{array}{c}0.487^{* * *} \\
(0.072)\end{array}$ & $\begin{array}{c}1.225^{* * *} \\
(0.078)\end{array}$ \\
\hline Assets & $\begin{array}{c}0.018 \\
(0.012)\end{array}$ & $\begin{array}{c}-0.00002 \\
(0.063)\end{array}$ & $\begin{array}{l}-0.005 \\
(0.079)\end{array}$ & $\begin{array}{l}-0.019 \\
(0.015)\end{array}$ & $\begin{array}{l}-0.004 \\
(0.007)\end{array}$ & $\begin{array}{l}-0.002 \\
(0.008)\end{array}$ \\
\hline Core deposits & $\begin{array}{c}0.04 \\
(0.121)\end{array}$ & $\begin{array}{c}0.159 \\
(0.411)\end{array}$ & $\begin{array}{l}-0.384 \\
(0.468)\end{array}$ & $\begin{array}{l}-0.043 \\
(0.096)\end{array}$ & $\begin{array}{l}-0.049 \\
(0.047)\end{array}$ & $\begin{array}{l}-0.009 \\
(0.065)\end{array}$ \\
\hline Liquid assets & $\begin{array}{l}-0.008 \\
(0.049)\end{array}$ & $\begin{array}{c}0.153 \\
(0.283)\end{array}$ & $\begin{array}{c}0.024 \\
(0.492)\end{array}$ & $\begin{array}{c}0.053 \\
(0.066)\end{array}$ & $\begin{array}{l}0.034 \\
(0.04)\end{array}$ & $\begin{array}{l}-0.045 \\
(0.031)\end{array}$ \\
\hline Leverage & $\begin{array}{l}-0.174 \\
(0.171)\end{array}$ & $\begin{array}{c}0.233 \\
(0.406)\end{array}$ & $\begin{array}{c}2.281 * * * \\
(0.833)\end{array}$ & $\begin{array}{c}-0.256^{* *} \\
(0.122)\end{array}$ & $\begin{array}{c}-0.073 \\
(0.09)\end{array}$ & $\begin{array}{c}0.221^{* * *} \\
(0.065)\end{array}$ \\
\hline Demand industry & $\begin{array}{c}0.03 \\
(1.451)\end{array}$ & $\begin{array}{c}0.574 \\
(11.27)\end{array}$ & $\begin{array}{l}-17.29 \\
(14.78)\end{array}$ & $\begin{array}{l}-1.393 \\
(2.777)\end{array}$ & $\begin{array}{l}0.453 \\
(1.28)\end{array}$ & $\begin{array}{c}1.74 \\
(1.747)\end{array}$ \\
\hline Demand households & $\begin{array}{c}0.886^{* * * *} \\
(0.273)\end{array}$ & $\begin{array}{c}2.506 \\
(1.949)\end{array}$ & $\begin{array}{l}-1.067 \\
(2.687)\end{array}$ & $\begin{array}{c}0.86 \\
(0.528)\end{array}$ & $\begin{array}{l}0.539^{*} \\
(0.276)\end{array}$ & $\begin{array}{c}0.35 \\
(0.293)\end{array}$ \\
\hline Demand world & $\begin{array}{c}0.161 \\
(0.717)\end{array}$ & $\begin{array}{l}-2.895 \\
(6.665)\end{array}$ & $\begin{array}{c}-19.53^{*} \\
(11.43)\end{array}$ & $\begin{array}{c}0.632 \\
(1.306)\end{array}$ & $\begin{array}{c}0.489 \\
(0.625)\end{array}$ & $\begin{array}{c}-1.73^{* * *} \\
(0.609)\end{array}$ \\
\hline Year-quarter FE & yes & yes & yes & yes & yes & yes \\
\hline Bank FE & yes & yes & yes & yes & yes & yes \\
\hline Observations & 3,332 & 3,332 & 3,332 & 3,332 & 3,332 & 3,332 \\
\hline R-squared & 0.045 & 0.02 & 0.033 & 0.039 & 0.06 & 0.279 \\
\hline Number of banks & 59 & 59 & 59 & 59 & 59 & 59 \\
\hline
\end{tabular}

Note: This table reports the results from estimating equation (1) for the period from 2001Q1 to 2016Q4 using OLS. The dependent variables are the change log of loans to private non-financial corporations (column 1), households (column 2), the public sector (column 3), resident financial institutions (column 4), the sum of the loans to these four sectors (column 5) and the change log of loans to non-residents (column 6). Standard errors clustered by bank are shown in parentheses. ${ }^{*}, * *$ and $* * *$ indicate statistical significance at the $10 \%, 5 \%$ and $1 \%$ level, respectively. 